\title{
5. CLAY MINERALOGY OF CENOZOIC SEDIMENTS FROM THE PERUVIAN CONTINENTAL MARGIN: LEG 112 1
}

\author{
T. Clayton ${ }^{2}$ and A.E.S. Kemp ${ }^{3}$
}

\begin{abstract}
Analysis of the clay mineralogy of 537 samples from Cenozoic sediments of the Peruvian forearc reveals distinctive geographic and stratigraphic patterns in the distribution of clay minerals. Post-Oligocene clay mineral assemblages show relatively constant illite-chlorite-kaolinite ratios with a variable expandable mineral component (smectite, vermiculite, and mixed-layer chlorite-vermiculite and/or chlorite-smectite). The distribution of Quaternary clay minerals is primarily controlled by provenance. In Quaternary assemblages from the Salaverry, Lima, and Trujillo basins, illite is more abundant than expandable minerals, and the expandable phase is primarily vermiculite, whereas in the Quaternary of the West Pisco Basin (Site 686), expandable minerals are more abundant than illite, and the expandable phase shows a substantial smectite component. This reflects low abundances of smectite in the source area between $4^{\circ}$ and $14^{\circ} \mathrm{S}$, which is a consequence of the Quaternary "volcanic gap" in this region. A change from smectite- to vermiculite-dominated assemblages during the Quaternary at Site 687 suggests relative uplift of the outer-shelf high at this time and isolation of the West Pisco Basin from the Lima Basin. The greater abundance of expandable phases seaward within the Quaternary is attributed to mixing of fluvial smectite-poor material with either smectite-rich eolian material or authigenic smectite, rather than differential settling. Slope sites exhibit a gradual increase in expandable minerals within the Quaternary. This may be explained in terms of a greater reworked shelf-derived component in the lower Quaternary. High-resolution studies of clay minerals at Sites 680 and 686 may provide some evidence of cyclicity. Most sites exhibit a sharp decrease in expandable minerals at or within the Quaternary or Pliocene. This is attributed to the reduction of volcanic activity associated with the progressive southward migration of the Nazca Ridge. At all sites, older sediments are characterized by smectite-rich assemblages, with smectite generally more abundant at depth. This is caused by the addition of allogenic and authigenic smectite from alteration of volcanic material, produced extensively during the Miocene and late Eocene.
\end{abstract}

\section{INTRODUCTION}

The clay mineralogy of sediments of the Peruvian continental margin has been the subject of several recent studies (Rosato and Kulm, 1982; Scheidegger and Krissek, 1982 and references therein). However, the majority of these studies were restricted to surface or shallow subsurface material. Drilling during Leg 112 recovered a comprehensive record of Cenozoic sedimentation along the Peruvian margin from Eocene time (Figs. 1, 2, 3). This gave us an opportunity to assess the relative importance and variation of tectonic, climatic, geographic, and paleoceanographic factors on the distribution of clay minerals within the region since the inception of the Andean mountain chain.

\section{METHODS}

The clay mineral composition of the $<2-\mu \mathrm{m}$ fraction of 537 samples was determined by X-ray diffraction (XRD). Samples were disaggregated in an ultrasonic tank using sodium hexametaphosphate as a dispersing agent. The resulting suspension was allowed to settle for a time calculated according to Stokes' law, and a $<2-\mu \mathrm{m}$ fraction was removed by decantation. This material was flocculated and magnesium-saturated using $\mathrm{MgCl}_{2}$, washed three times, and centrifuged to produce a thick paste. The paste was smeared onto glass slides, and the following X-ray scans performed: (1) air-dried $2^{\circ}$ to $14^{\circ} 2 \theta,(2)$

\footnotetext{
${ }^{1}$ Suess, E., von Huene, R., et al., 1990. Proc. ODP, Sci. Results, 112. College Station, TX (Ocean Drilling Program).

2 Department of Geology, University of Southampton, Southampton, United Kingdom.

${ }^{3}$ Department of Oceanography, University of Southampton, Southampton, United Kingdom.
}

glycolated $2^{\circ}$ to $34^{\circ} 2 \theta$, (3) heated $\left(550^{\circ} \mathrm{C}\right) 2^{\circ}$ to $14^{\circ} 2 \theta$, using nickel-filtered $\mathrm{CuK} \alpha$ radiation and a scanning velocity of $2^{\circ} 2 \theta / \mathrm{min}$. In addition, selected samples were scanned after heating to $375^{\circ} \mathrm{C}$ and/or after treatment with glycerol. Semiquantitative analysis was conducted on the basis of peak area in the manner of Biscaye (1965). No attempt was made to chemically remove opaline silica or carbonate before X-ray examination. Consequently, several samples gave very low intensities because of dilution and/or disruption of orientation by fine-grained siliceous matter. However, even in these cases, a qualitative analysis was usually possible. Such samples are represented by a cross on the diagrams; numerical data are not plotted.

\section{RESULTS}

All samples contain abundant to dominant amounts of expanding clay minerals. In many samples, particularly of Eocene to early Miocene age, the expanding phase is clearly a well-crystallized smectite (Fig. 4). This gave an air-dried peak at $15 \AA$, which expanded on glycolation to give a sharp $17 \AA$ peak with integral $(002)$ and higher-order reflections. On heating at $550^{\circ} \mathrm{C}$, the 001 peak collapsed to $9.6 \AA$. Treatment of selected samples with glycerol showed similar expansion. Other samples showed dominant smectite, but with broader peaks and less obvious higher-order reflections.

Many samples, particularly of Quaternary age, gave an air-dried peak at $14 \AA$, which collapsed to $10 \AA$ when heated, but showed variable expansion on glycolation. This ranged from virtually nil to a maximum peak at $16.3 \AA$. Treatment of selected samples of this type with glycerol resulted in little or no expansion (Fig. 5). Such behavior would be characteristic of vermiculite possessing a range of layer charges (McEwen and Wilson, 1981). In between these extremes, 
A

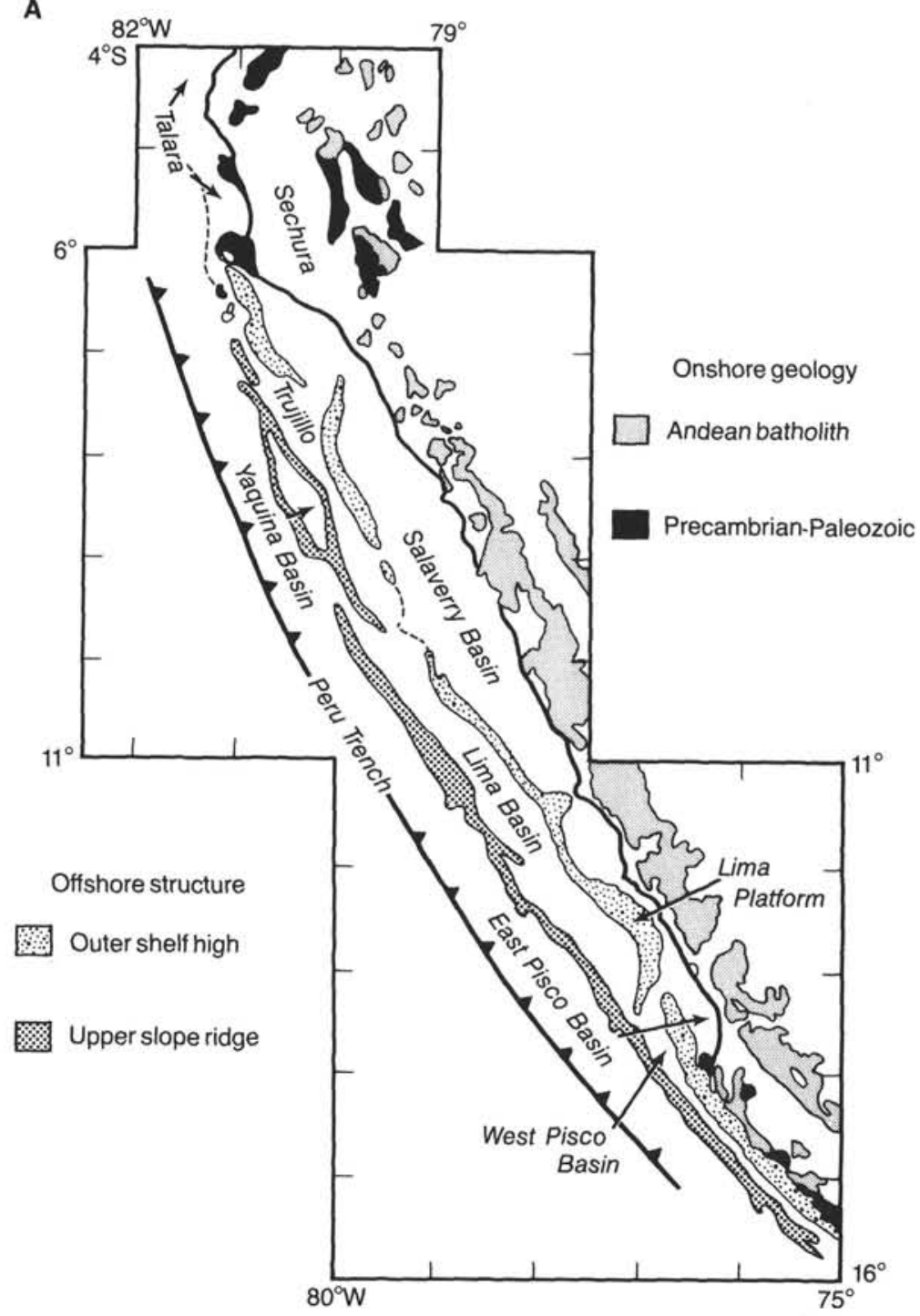

B

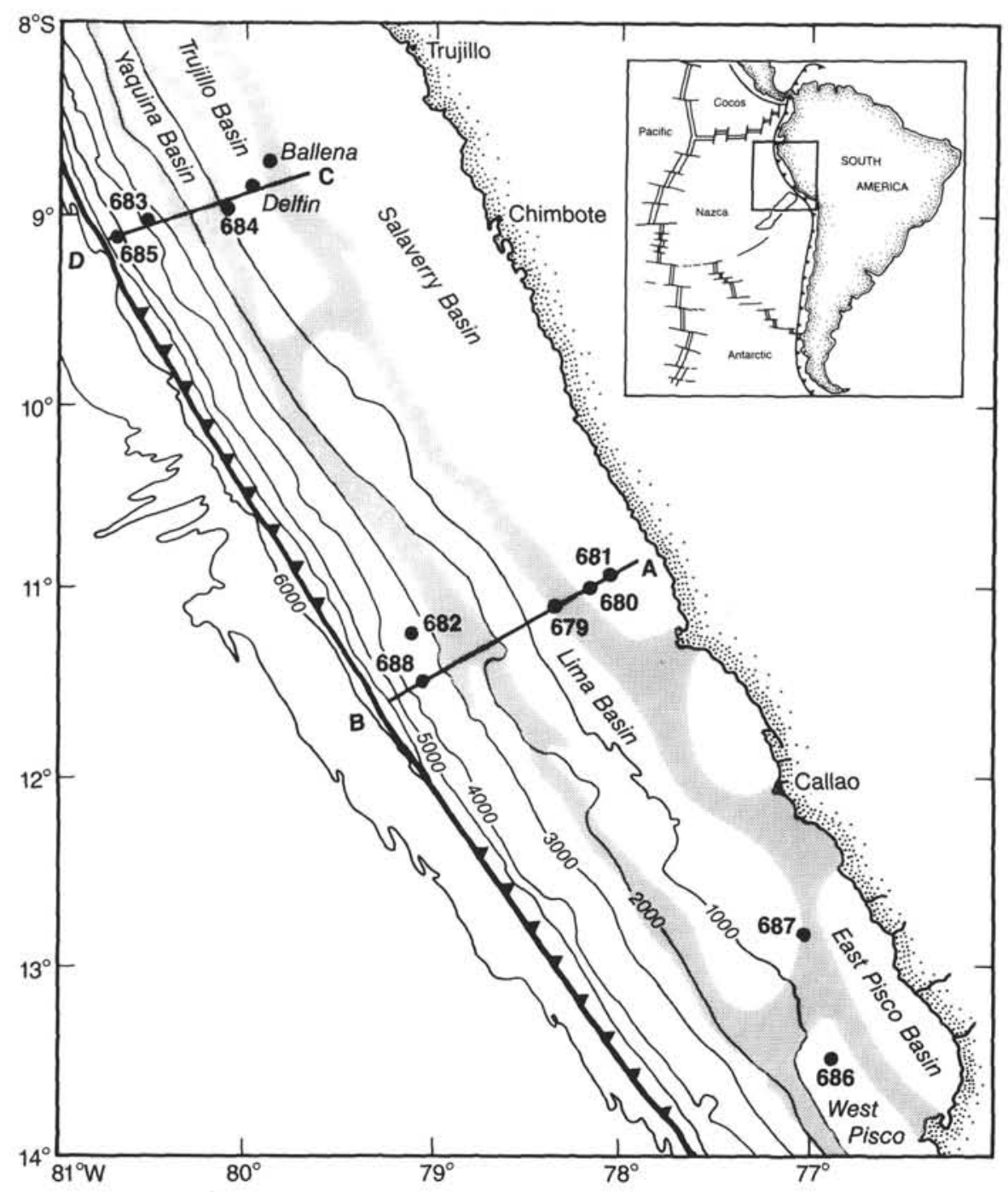

Figure 1. A. Major forearc basins along the Peruvian continental margin, onshore and offshore structures that control the distribution of these sedimentary basins. B. Locations of sites drilled during Leg 112 and structural transects shown in Figures 2 and 3 (from Suess, von Huene, et al., 1988). 


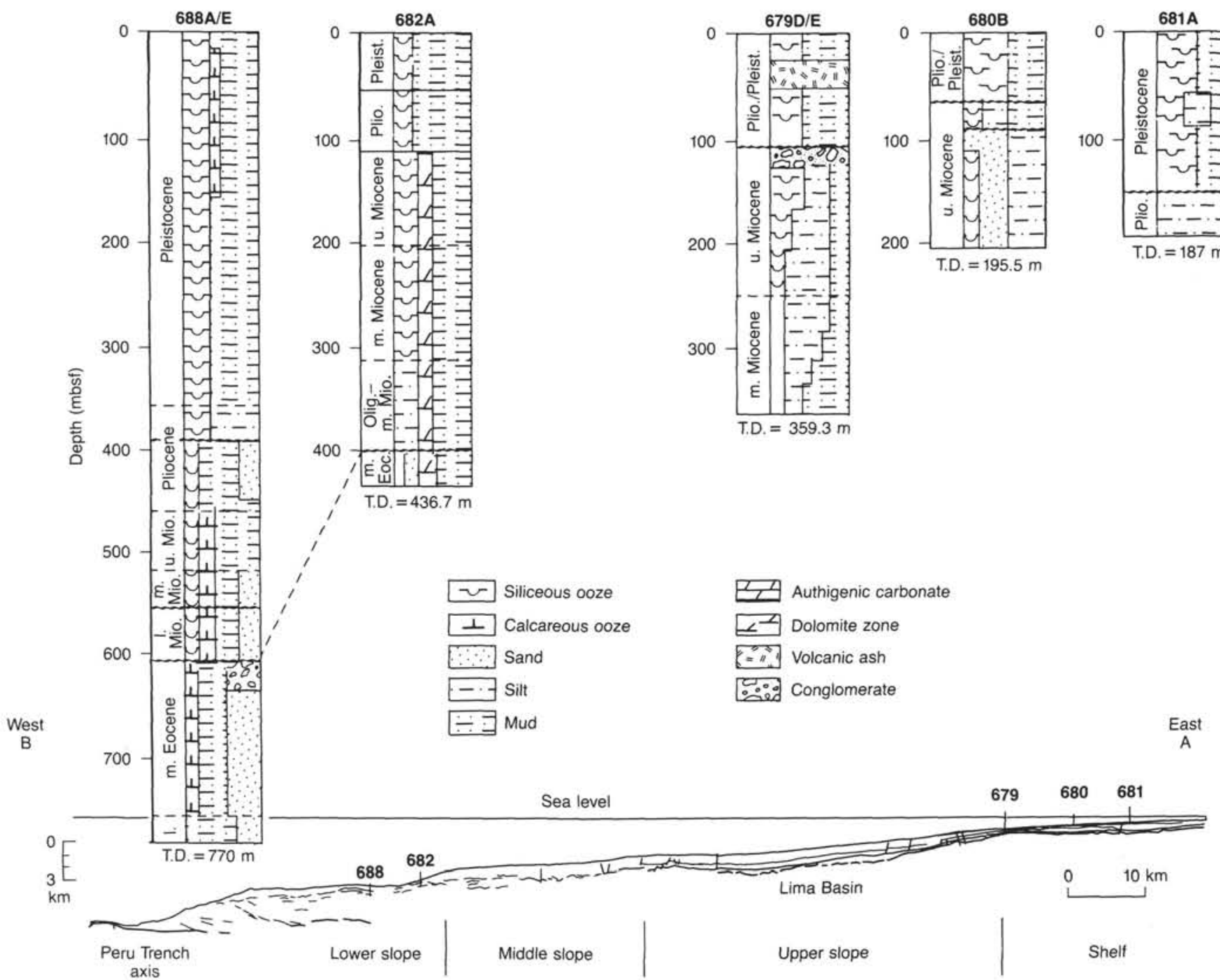

Figure 2. Simplified structural transect based on seismic survey and results of Leg 112 across the Peruvian margin at $9^{\circ} \mathrm{S}$ (from Suess, von Huene, et al., 1988).

many samples showed a broad peak between 14.5 and $17 \AA$, presumably corresponding to a mixture of both smectite and vermiculite.

Many samples also exhibited a small broad peak at approximately $12 \AA$ in the $550^{\circ}$ trace. This was interpreted as smectite/chlorite and/or vermiculite/chlorite. Rosato and Kulm (1981) reported the presence of a $16.3 \AA$ (glycolated) phase in Quaternary surface and subsurface sediments from the Peru continental margin, which they identified as chlorite/smectite. Although a chlorite/swelling-mineral phase is clearly present in many samples, the considerable enhancement of the $10 \AA$ peak when heated to $375^{\circ} \mathrm{C}$ indicates that a major proportion of the $16.3 \AA$ peak is fully collapsing and must be due to vermiculite. A further complication exists in that the air-dried peak centered at $14 \AA$ is often asymmetric toward higher angles. This is due either to incomplete hydration in the air-dried state, or to the presence of illitic interlayers. Such complex assemblages are common in soil weathering profiles, particularly where primary ferromagnesian minerals are present and the soil is immature (Velde, 1985).

Because of the complexity and overlapping nature of the expanding mineral phases present, it was not possible to provide individual estimates of their abundance. Instead, the "total" abundance of "expandable minerals" (E) was estimated on the basis of the diffracted peak area between 14.5 and $18 \AA$ in the glycolated trace. A constant "intensity factor" was used to convert this peak area into relative concentration with respect to illite, as in the method of Biscaye (1965). However, different expanding phases are unlikely to have identical intensity factors, and the use of a constant factor in this way might be expected to cause systematic errors in the estimation of $\mathrm{E}$, depending on the expanding phases present. This problem is not confined to expanding minerals, but applies to most XRD estimates of clay minerals, where individual mineral phases consist of structurally and chemically variable material from a variety of sources. Consequently, routine estimates of clay minerals must be regarded as relative at best, and the possibility of systematic errors must be borne in mind. In the present study, it was considered preferable to estimate total expandable materials in a reproducible manner, rather than to attempt a subjective and arbitrary division into separate phases. However, some indication of whether vermiculite or smectite is the dominant expanding phase is given by the position of the maximum intensity on the glycolated trace in the 14 to $17 \AA$ region. This is shown in Figures 6 through 15. 


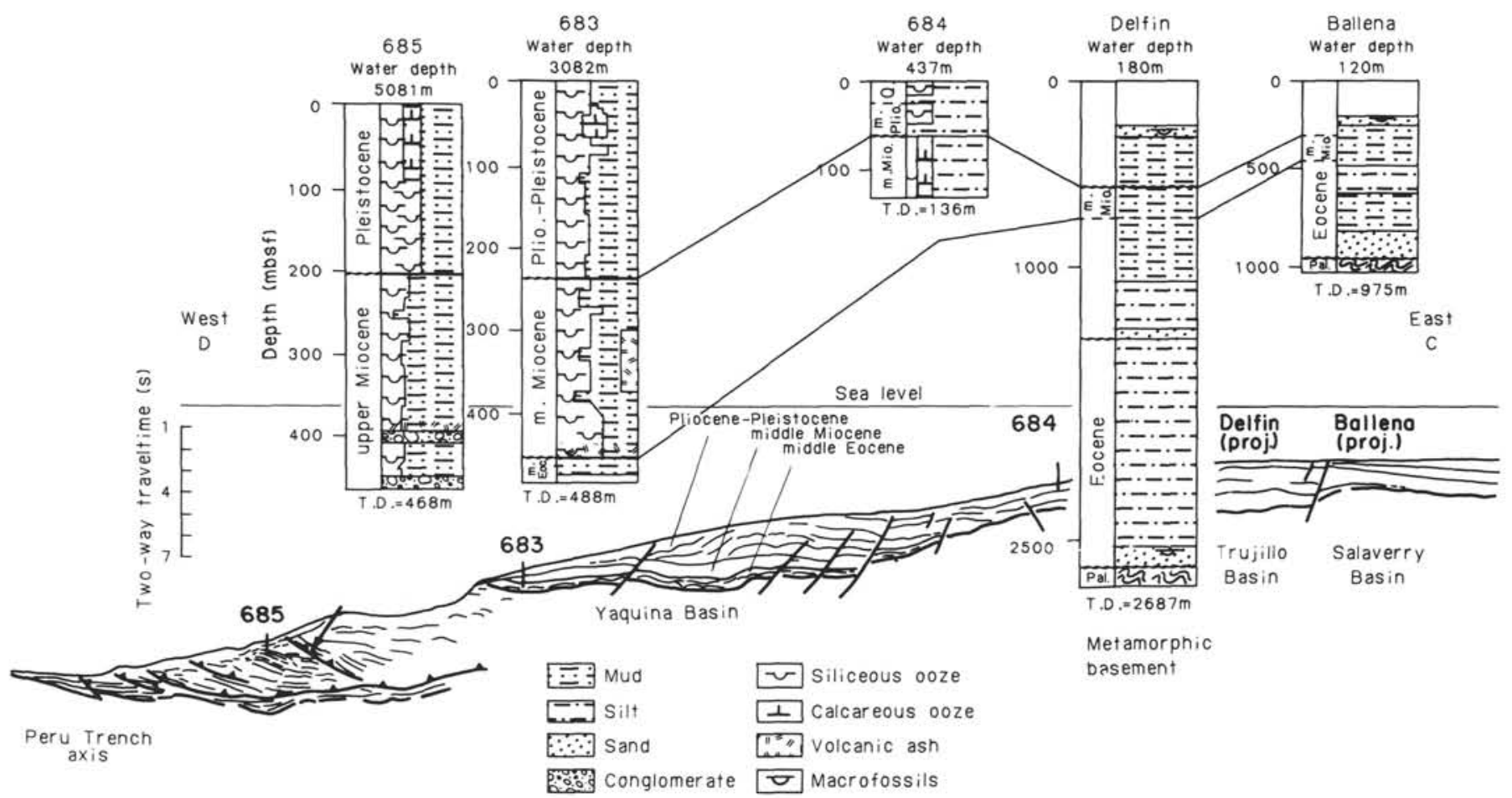

Figure 3. Simplified structural transect, based on seismic survey and results of Leg 112 across the Peruvian margin at $11^{\circ} 30^{\prime}$ S (from Suess, von Huene, et al., 1988).

Estimation of the relative amounts of kaolinite and chlorite is based on resolution of the (002) kaolinite peak/(004) chlorite peak. Such a procedure is relatively inaccurate, particularly where low intensities or broad peaks are involved.

\section{Site 679}

Site 679 is situated in the southern transect just beyond the edge of the continental shelf (Fig. 1). The distribution of clay minerals with depth is shown in Figure 4.

The Quaternary muds of lithologic Unit I are characterized by an "expandable minerals"/illite (E/I) ratio of approximately 1 . Although only five specimens were taken, all show a broad 001 peak, with a maximum at $16.3 \AA$ on glycolation. One sample $(112-679 \mathrm{D}-2 \mathrm{H}-1,120 \mathrm{~cm})$ was treated with glycerol. This resulted in only slight expansion to give a small peak at $17 \AA$. Thus the expandable minerals in this unit seem to be mainly vermiculite, with only a minor smectite component.

At the boundary between Units I and II, within the Quaternary succession, a relatively sharp increase in E/I ratio from 1 to 2.5 occurs. Within Units II and III (Quaternary to upper Miocene), the E/I ratio appears to increase gradually from 2.5 to 5 with depth. The 001 peak is broad and variable, showing a range of diffracted intensity from $17 \AA$ to $14 \AA$, corresponding to a mixture of both smectite and vermiculite phases. The position of the peak maximum migrates from about $16.2 \AA$ to about $16.8 \AA$ with depth, showing that the smectite fraction of the expandable minerals increases with depth as the overall E/I ratio increases. Small amounts of clinoptilolite are present below $190 \mathrm{~m}$.

Below the hiatus at about $4 \mathrm{Ma}(245 \mathrm{~m})$, middle Miocene sediments show a clay mineral composition dominated by highly crystalline smectite accompanied by clinoptilolite. The E/I ratio ranges between 5 and 30 .

Although the E/I ratio increases considerably with depth, the nonexpanding clay minerals show much less variation in their relative abundance. Above $245 \mathrm{~m}$, the chlorite plus kaolinite/illite ratio ranges from 0.3 to 0.5 and, where it can be reasonably accurately determined, the kaolinite (002)/chlorite (004) ratio lies between 0.3 and 0.6 . Illite, kaolinite, and chlorite co-vary, and differences in the composition of the clay minerals mainly result from variation with respect to expandable minerals. Vermiculite seems to be antipathetic to smectite in that increasing $\mathrm{E} / \mathrm{I}$ ratios invariably correspond to increasing smectite dominance.

Below $245 \mathrm{~m}$, the low intensities of the $10 \AA$ and $7 \AA$ peaks make illite, kaolinite, and chlorite ratios difficult to measure accurately, but they appear to be similar to the rest of the succession.

\section{Site 680}

Site 680 is located in the central part of the Salaverry Basin and represents the middle of the Sites 679-680-681 transect. The Quaternary section shows an average E/I ratio of 0.8 , slightly lower than that of the upper Quaternary of Hole 679D. As in Hole 679D, the expandable phase is dominated by vermiculite. Sample 112-680D-2H-2, $128 \mathrm{~cm}$, at $8.28 \mathrm{~m}$, however, is anomalous, showing an E/I ratio of 1.8 and a prominent $17 \AA ̊$ smectite spacing. Closer sampling will be required to establish the range of this anomaly.

There may be a broad correlation between organic content (see Suess et al., this volume) and E/I ratio, particularly above $20 \mathrm{~m}$, although this has not been verified statistically.

As at Site 679, a relatively sharp transition exists between sediments having an E/I ratio of 1 , and those below having a value greater than 2 . The transition coincides with the hiatus separating the Quaternary from the Pliocene. This may occur stratigraphically lower in this hole (i.e. below the Quaternary/ Pliocene boundary) than in Hole 679D, where it occurs within the Quaternary. As at Site 679, the E/I ratio increases with depth, reaching a value of 5 at the bottom of the hole. This may be partly facies-related, in that the lower part of lithologic Unit III contains more terrigenous clastics. 


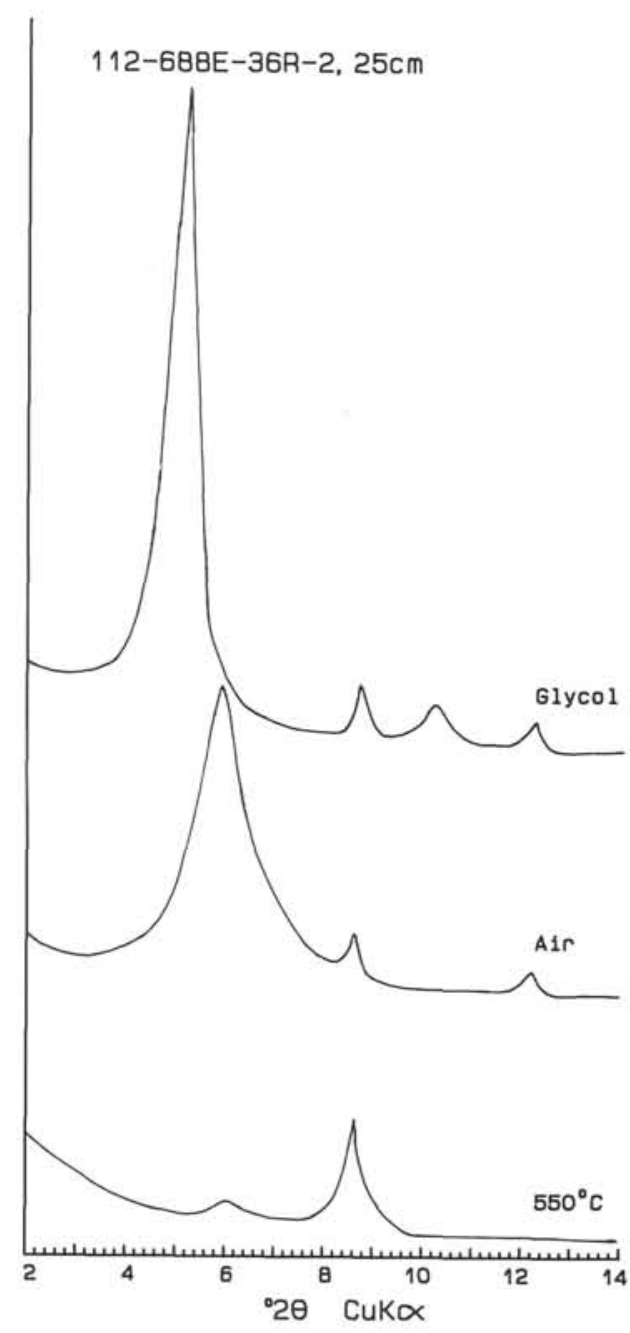

Figure 4. XRD pattern of Sample 112-688E-36R-2, $25 \mathrm{~cm}$, illustrating highly crystalline smectite.

The chlorite plus kaolinite/illite ratio is almost constant throughout the hole and is virtually identical to that observed in Hole 679D.

\section{Site 681}

Site 681 represents the most landward site drilled. Only sediments of Quaternary age were recovered. In the upper part of the succession (above $65 \mathrm{~m}$ ), the composition of the clay minerals is characterized by E/I ratios averaging 0.7 , corresponding to a slightly lower expandable mineral component than in the Quaternary succession of the two preceding wells. As in the two previous wells, the chlorite plus kaolinite/ illite ratio is virtually constant.

The E/I ratio increases with depth. An "ash" sample at $112-681 \mathrm{~B}-10 \mathrm{H}-2,19 \mathrm{~cm}$, shows a slightly greater E/I ratio (1.3) and a $17 \AA$ smectite peak.

\section{Site 682}

Sites 682 and 688 are situated close together on the lower slope of the Peru continental margin. They exhibit similar clay mineral trends. In Site 682, the Quaternary succession shows an average $\mathrm{E} / \mathrm{I}$ ratio just above 1 , slightly higher than those observed in the shelf and upper-slope sites $(679,680$, and 681). As with the previous sites, the expandable phase seems to be mainly vermiculitic. A sharp transition from $\mathrm{E} / \mathrm{I}$ values of 1 to

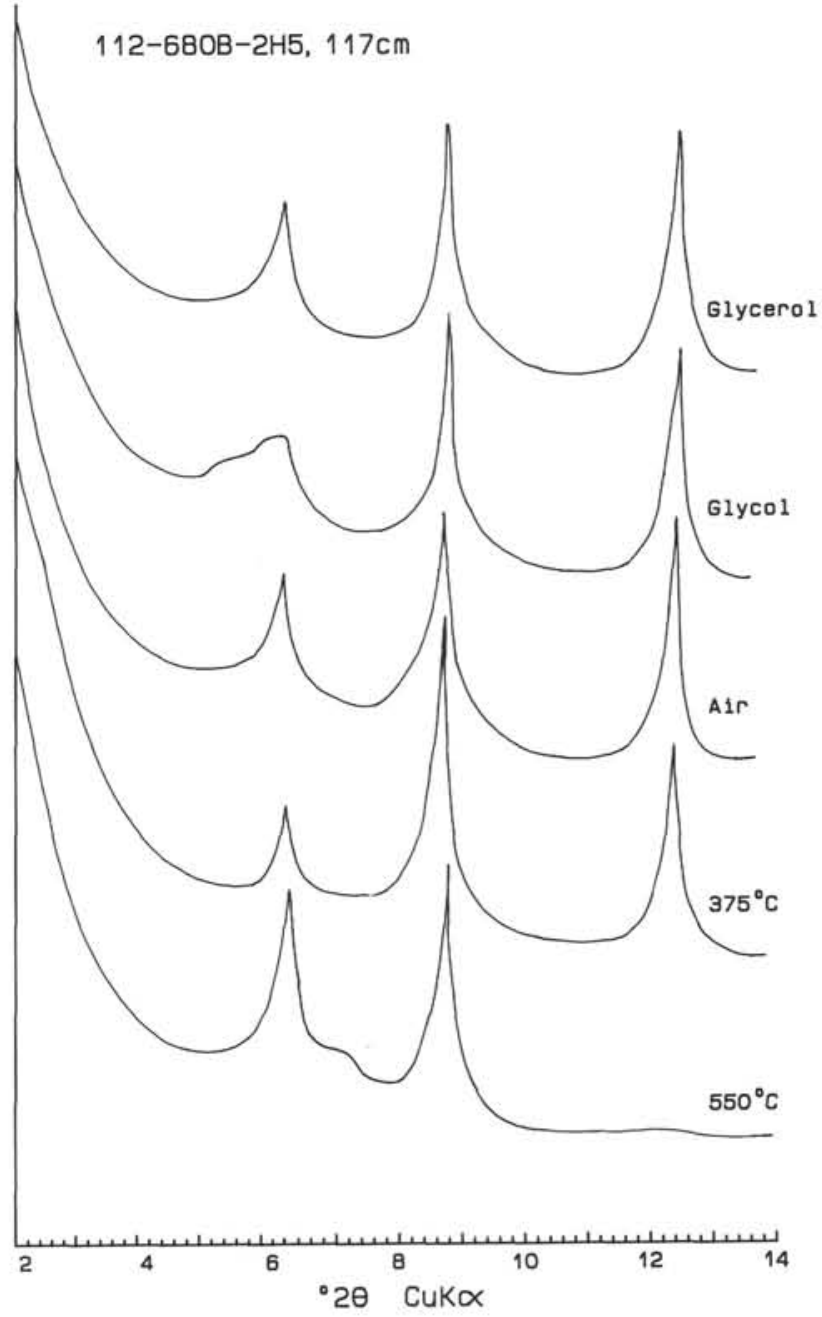

Figure 5. XRD pattern of Sample 112-680B-2H-5, $117 \mathrm{~cm}$, illustrating the presence of vermiculite plus minor chlorite-vermiculite or chlorite-smectite.

E/I values between 2.5 and 7 occurs within the Pliocene, and these values persist until the base of lithologic Unit II at $311 \mathrm{~m}$ in the middle Miocene. Unlike previous sites, no evidence exists of a gradual increase in expanding phases within these units.

Below $311 \mathrm{~m}$, middle Miocene to Eocene sediments at both sites are dominated by moderate- to highly-crystalline smectite having $\mathrm{E} / \mathrm{I}$ ratios between 11 and 25 . The illite/chlorite ratio is commonly $2: 1$; again, quite different from that observed in younger sediments. Clinoptilolite is present in the upper part of the Eocene succession at Site 686, and palygorskite was observed in two samples.

The chlorite plus kaolinite/illite ratio is, on average, slightly lower than those observed in the shelf sites. However, this ratio exhibits little variation downhole in comparison with the differences observed in the E/I ratios.

\section{Site 688}

As in nearby Site 682 , the Quaternary succession of Site 688 shows an average E/I ratio just above 1, slightly higher than those observed in the shelf and upper-slope sites (679, 680 and 681). A slight decrease occurs in the E/I ratio in the top $100 \mathrm{~m}$. A sharp transition from E/I values of 1 to E/I values between 2.5 and 7 occurs within the Pliocene, and these 


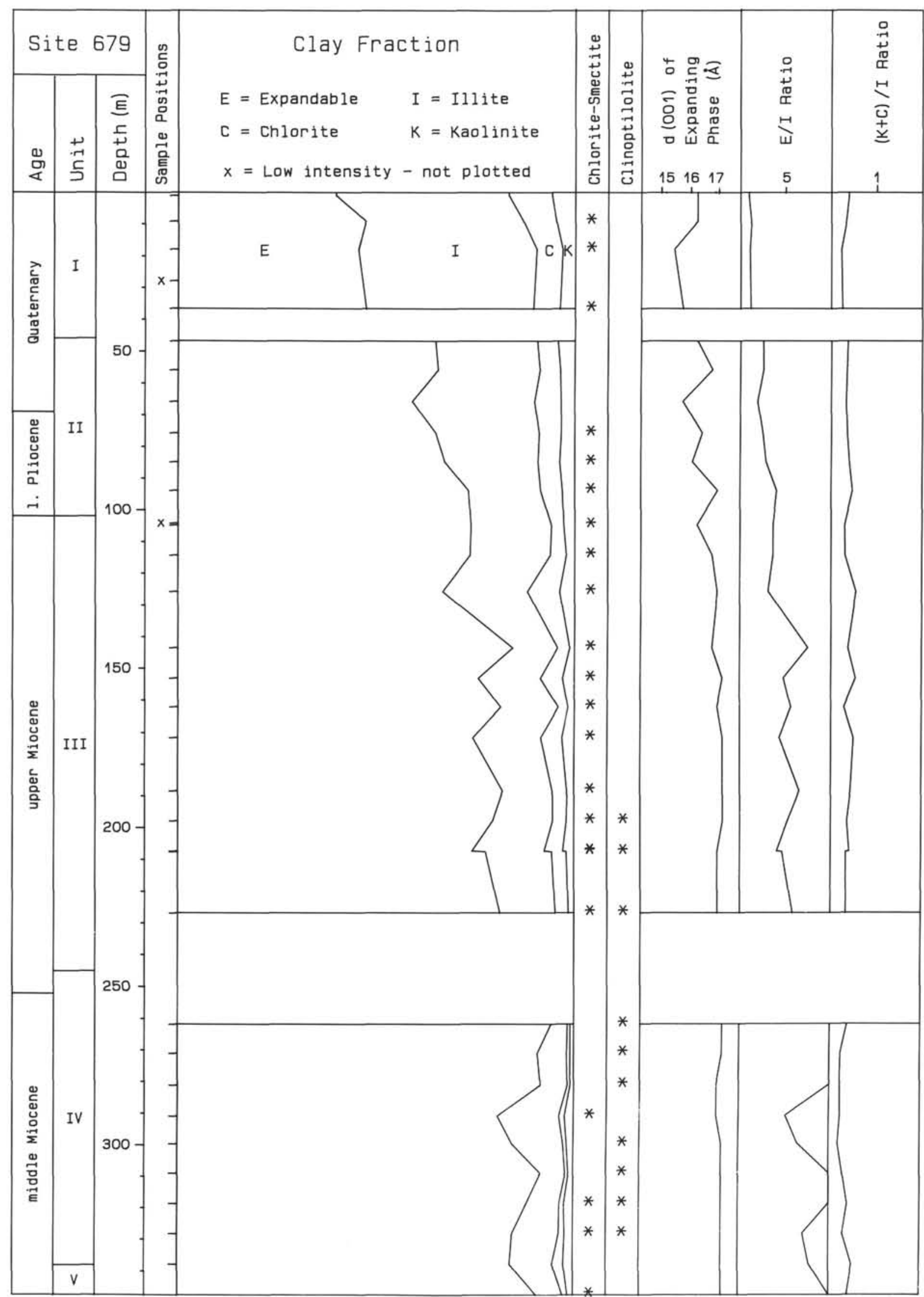

Figure 6. Clay-mineral data from Site 679. 


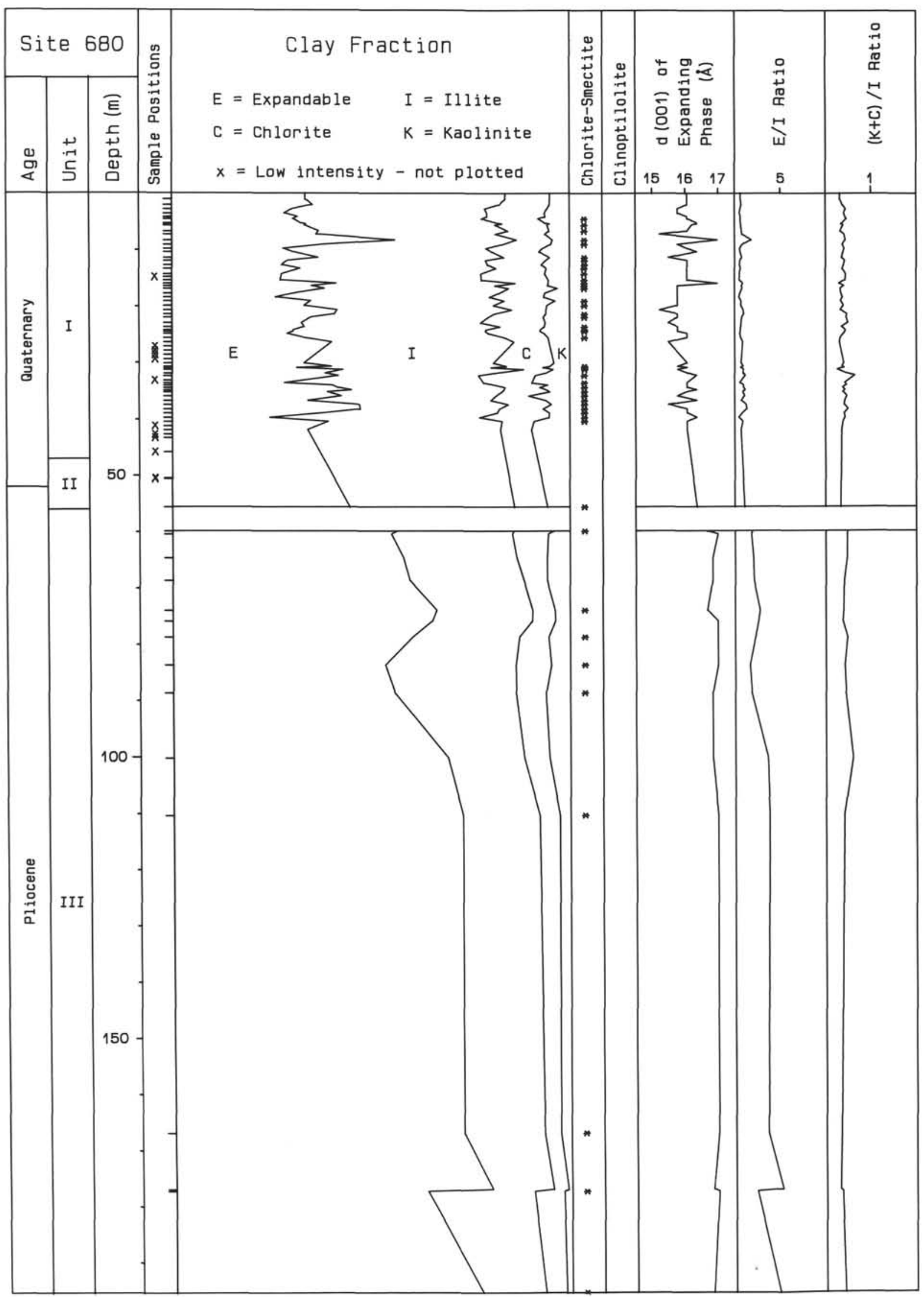

Figure 7. Clay-mineral data from Site 680. 
T. CLAYTON, A.E.S. KEMP

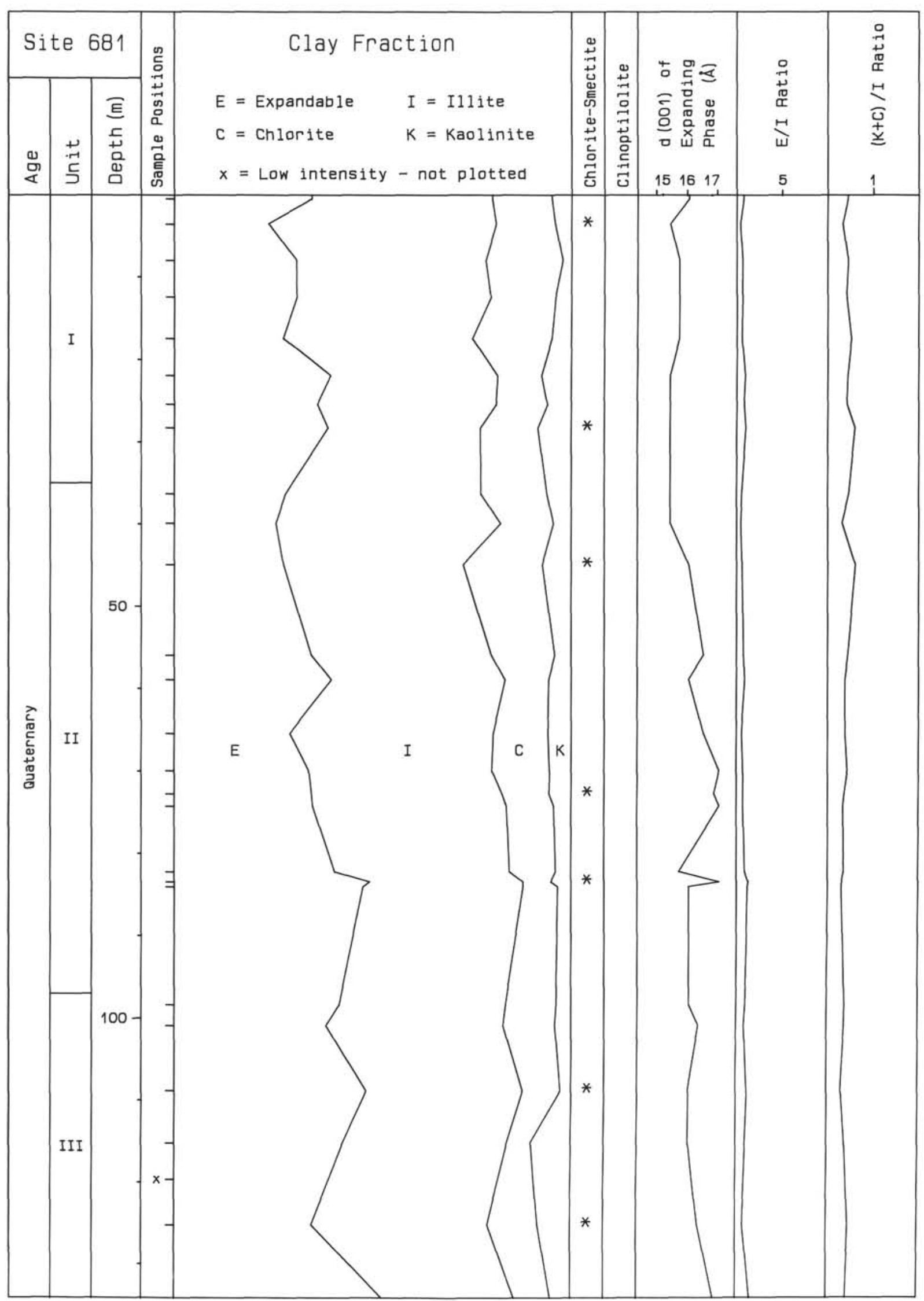

Figure 8. Clay-mineral data from Site 681.

66 


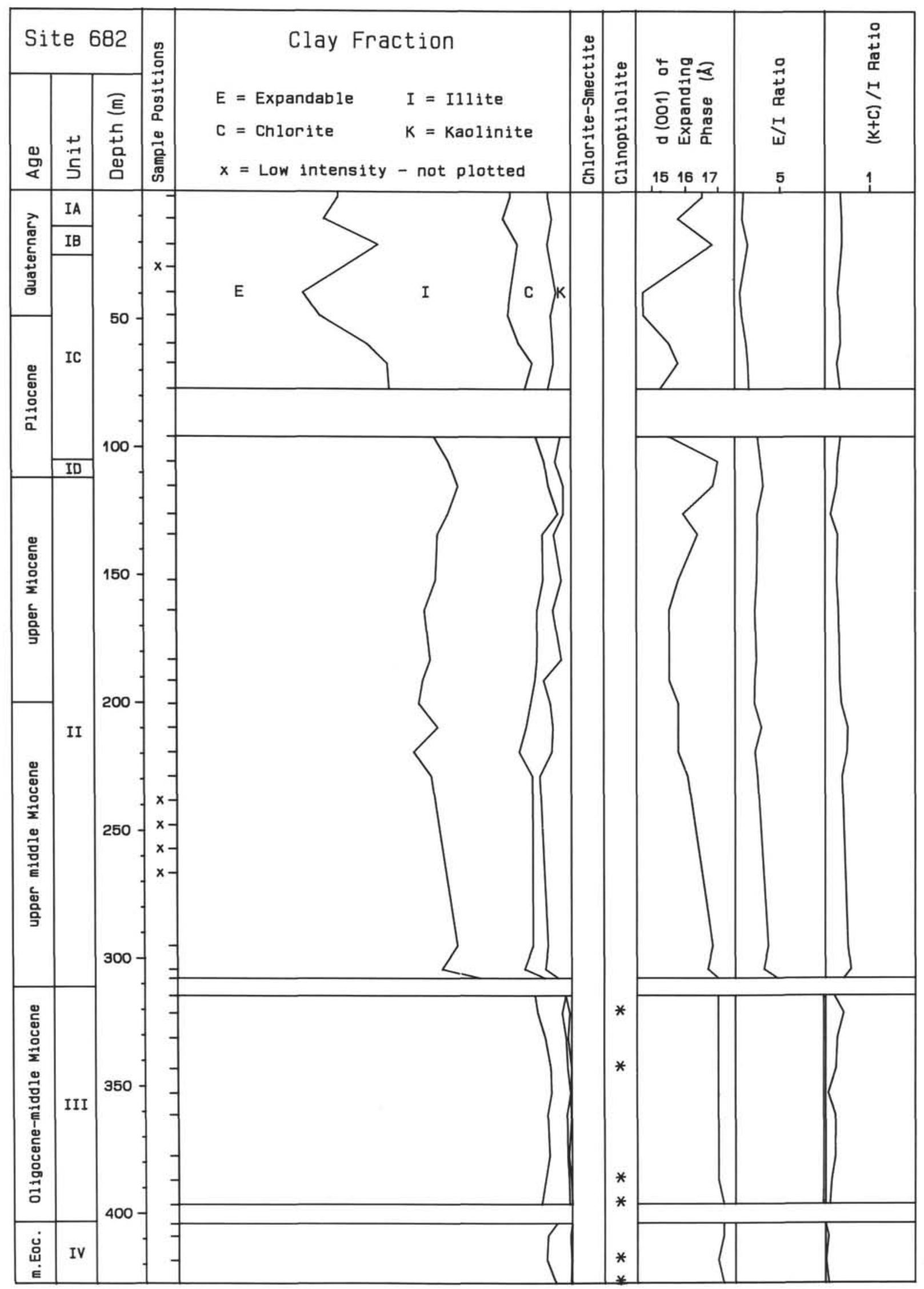

Figure 9. Clay-mineral data from Site 682. 


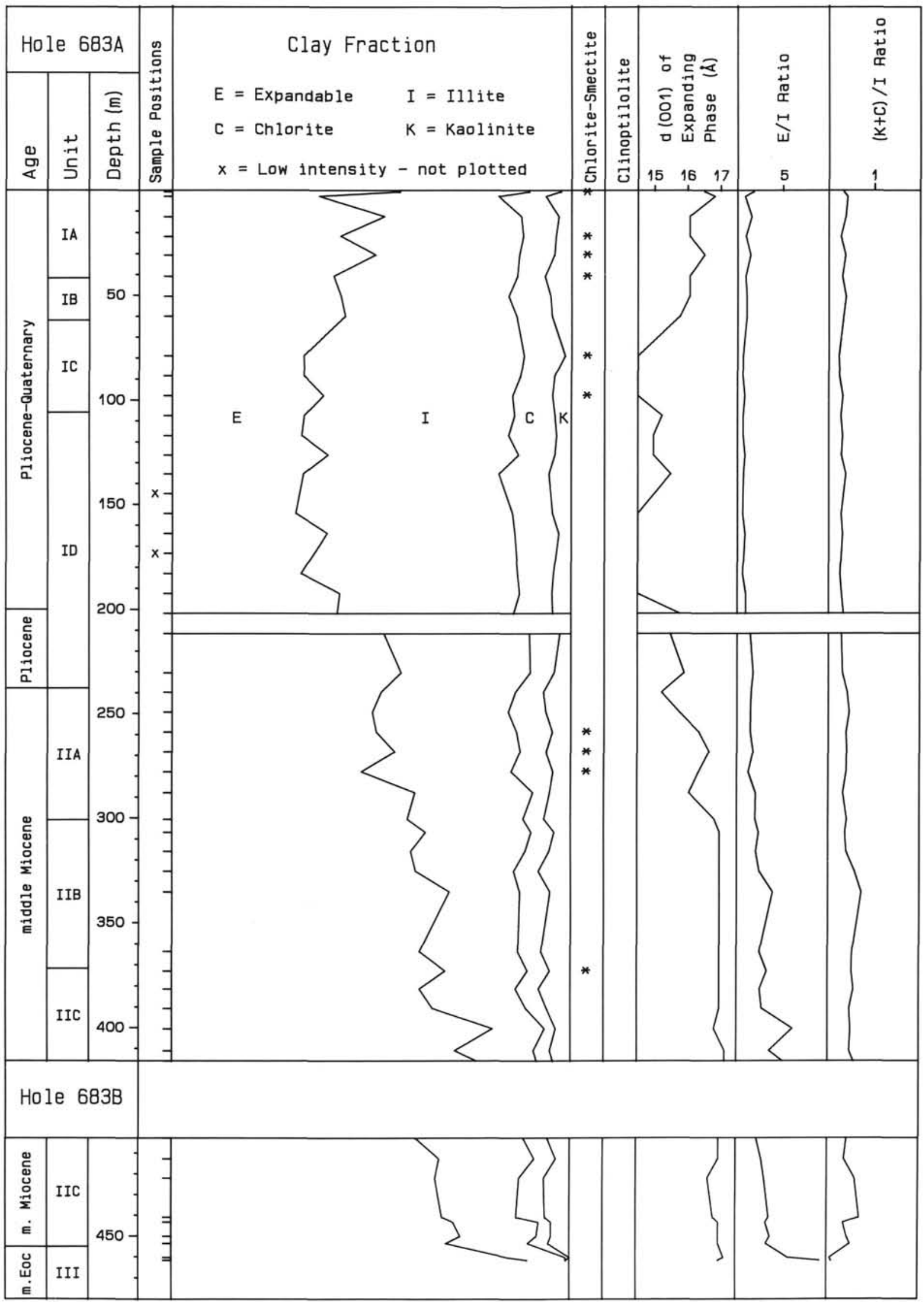

Figure 10. Clay-mineral data from Site 683. 


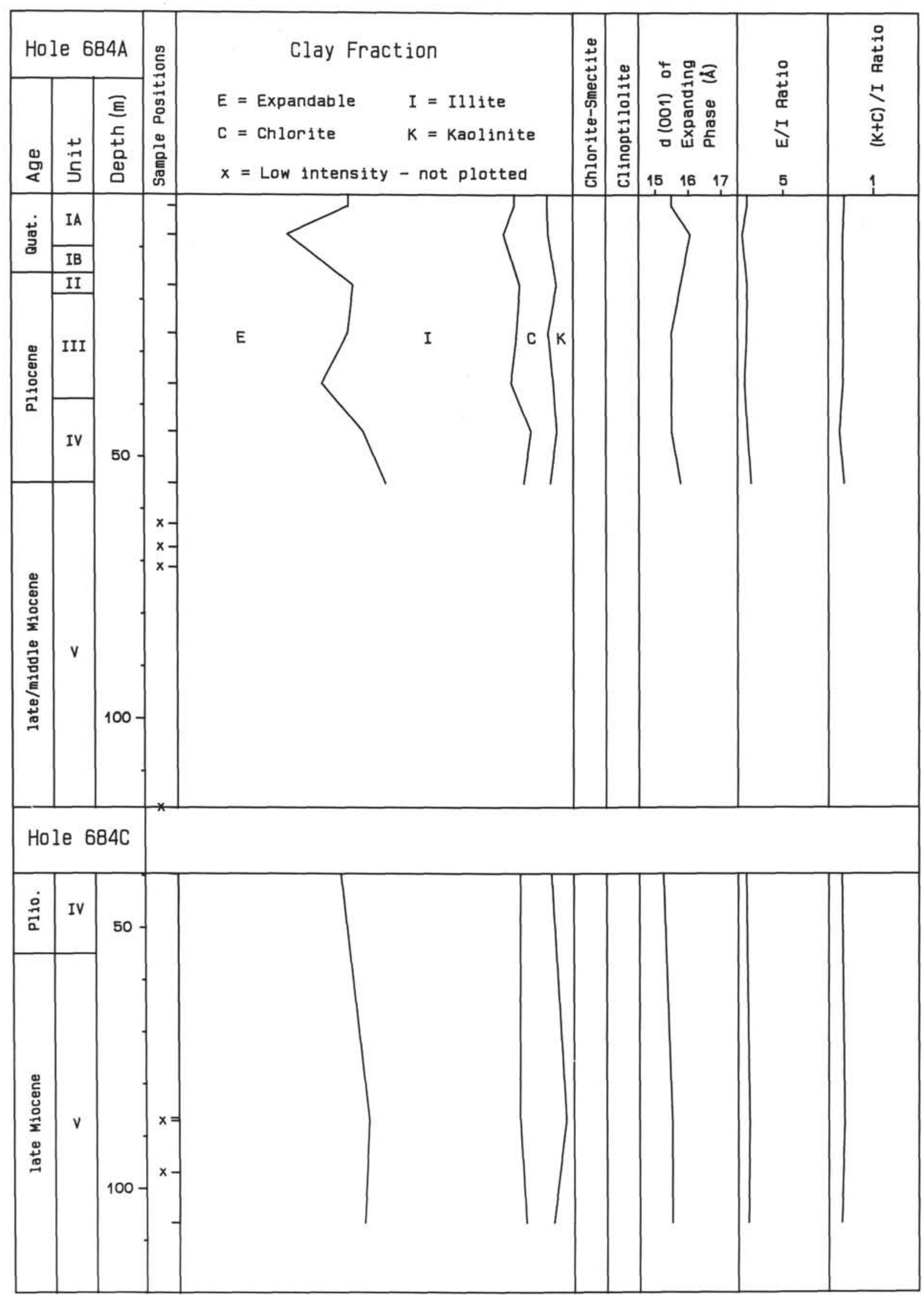

Figure 11. Clay-mineral data from Site 684. 


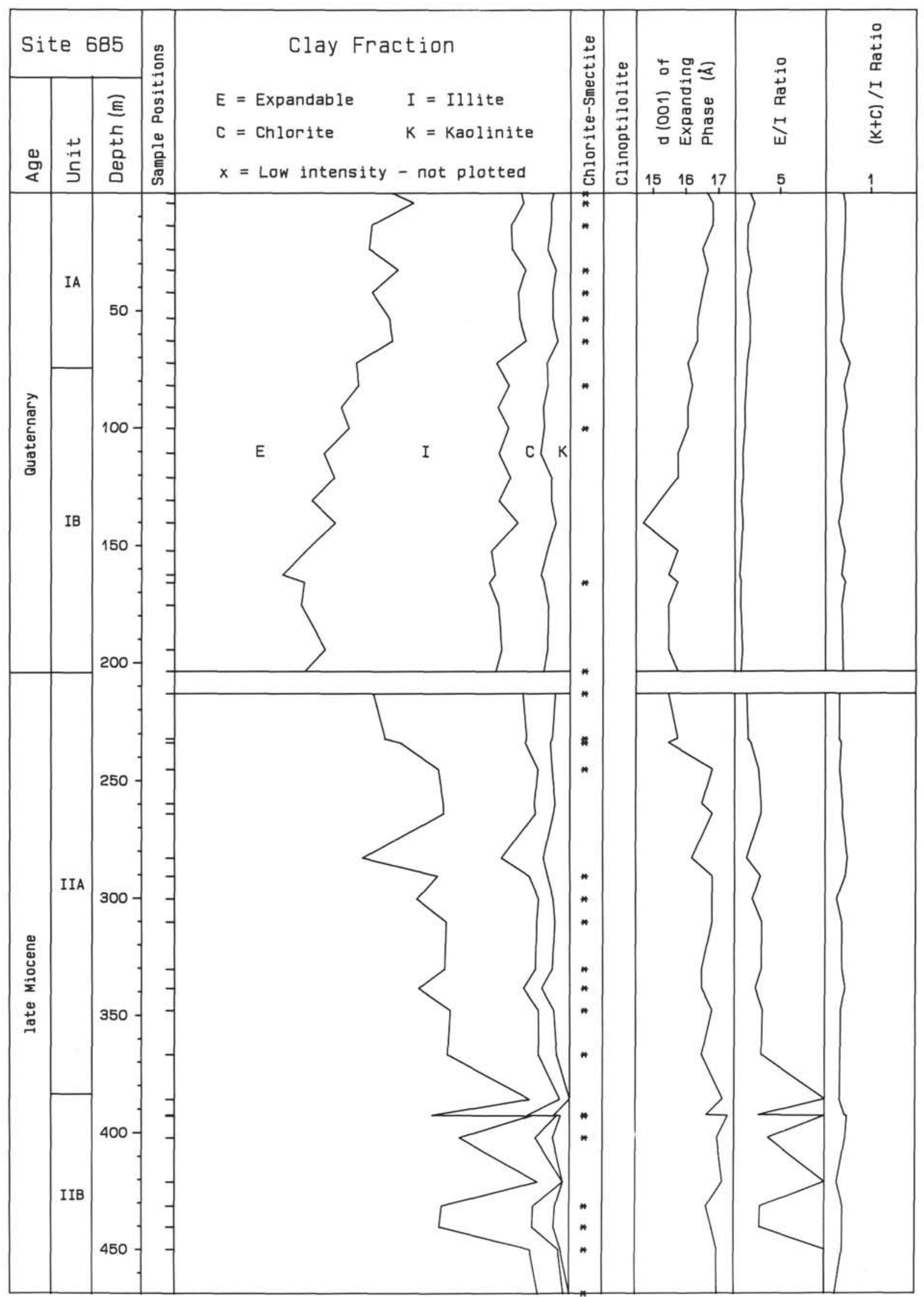

Figure 12. Clay-mineral data from Site 685. 
CLAY MINERALOGY OF CENOZOIC SEDIMENTS

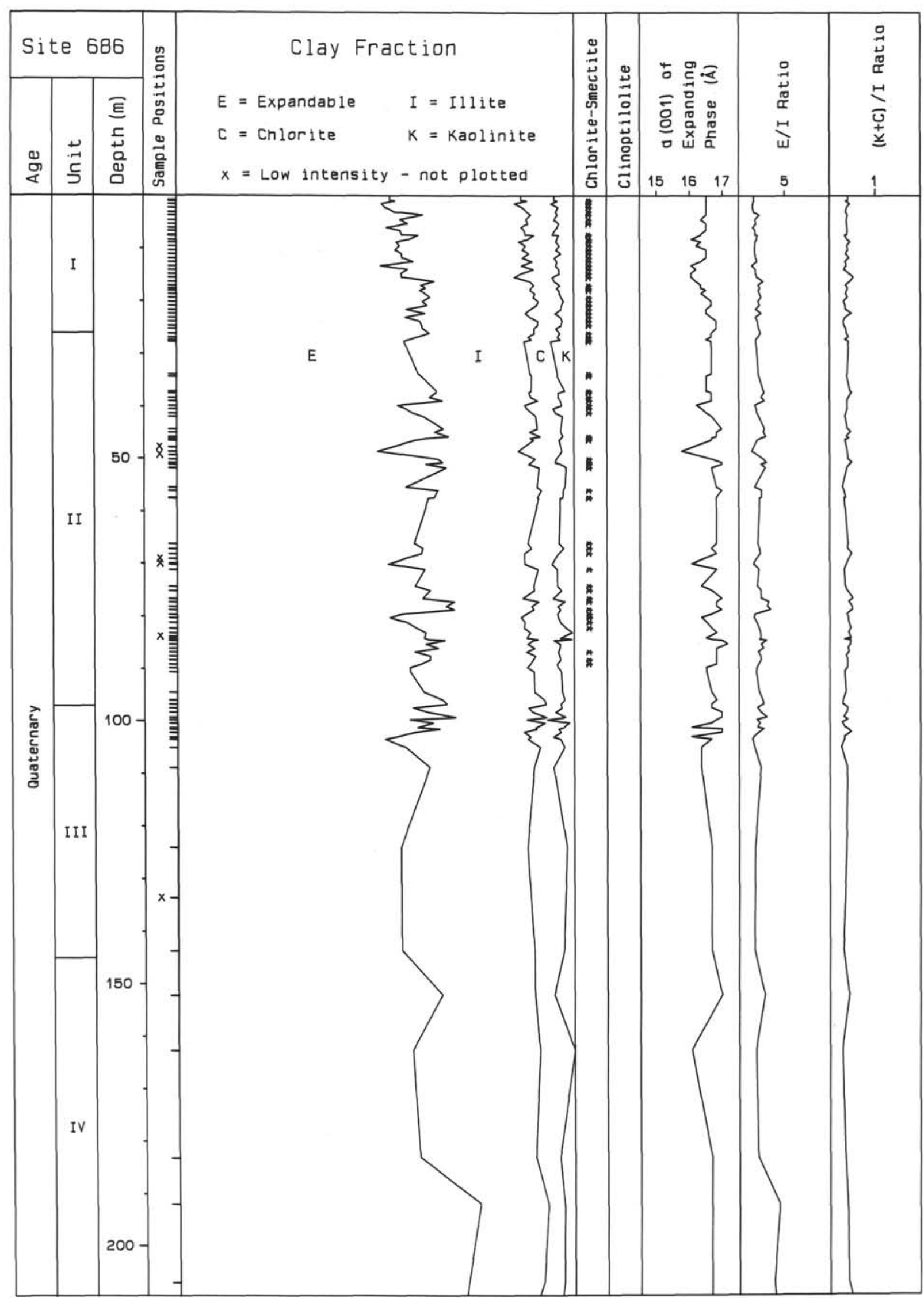

Figure 13. Clay-mineral data from Site 686. 
T. CLAYTON, A.E.S. KEMP

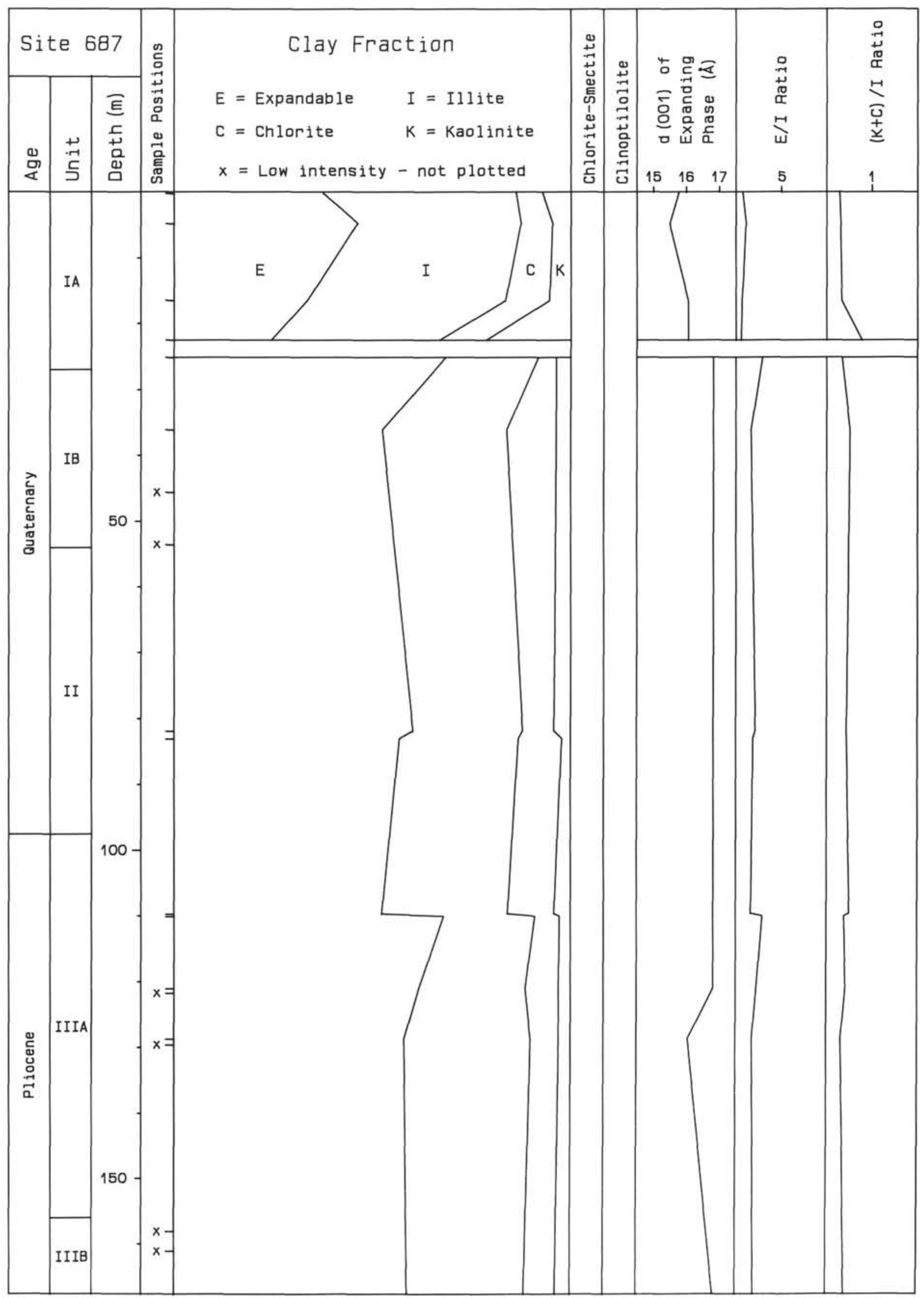

Figure 14. Clay-mineral data from Site 687. 
CLAY MINERALOGY OF CENOZOIC SEDIMENTS

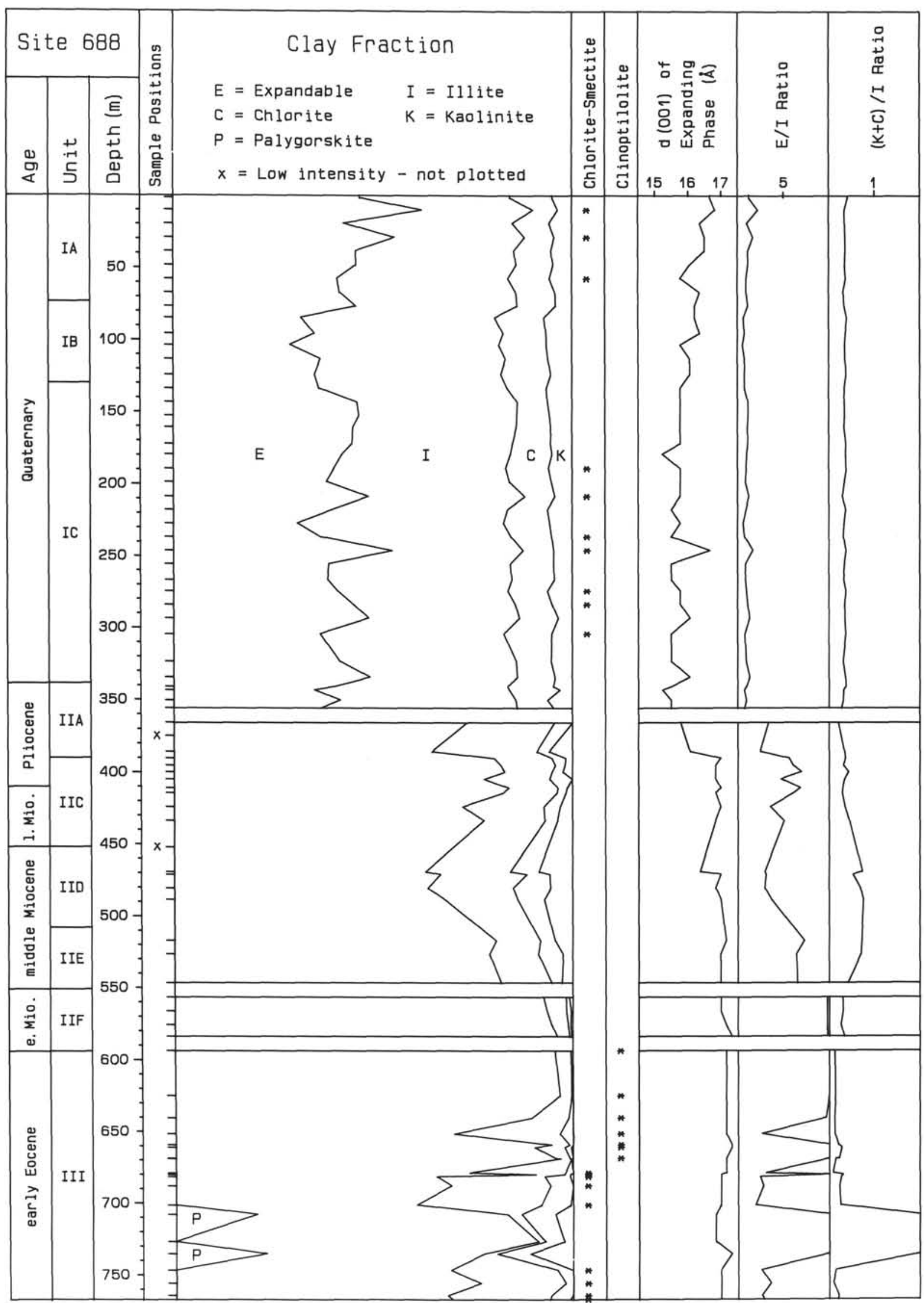

Figure 15. Clay-mineral data from Site 688. 
values persist until the base of the middle Miocene. The chlorite plus kaolinite/illite ratio remains remarkably constant, with values virtually identical to those at Site 682 .

Lower Miocene sediments are dominated by smectite with $\mathrm{E} / \mathrm{I}$ ratios between 16 and 32 . The smectite is highly crystalline. The chlorite plus kaolinite/illite ratio is difficult to determine accurately, but appears to be similar to the sediments above.

All the upper Eocene sediments of Site 688 are dominated by smectite, but the crystallinity of the smectite and the nature and abundance of the minor phases is variable. The $\mathrm{E} / \mathrm{I}$ ratio ranges from 2.5 to 50 . The illite is considerably more crystalline than that observed in the younger sediments, and the kaolinite:chlorite:illite ratios are much more variable. This variability may be facies related. Opal-CT, low cristobalite, and clinoptilolite are present, and palygorskite was observed in two samples, both carbonate-bearing.

\section{Site 684}

Site 684 is situated just beyond the edge of the shelf in the northern transect (Fig. 1). Although only a limited number of samples were taken and many gave only low intensity clay peaks, the E/I ratio does not change significantly from late Miocene to Pleistocene time, averaging approximately 1 throughout. It is mainly vermiculitic in character. This contrasts markedly with all other sites, which generally show an increase in expandable phases with depth.

\section{Site 683}

As in the southern transect, the Quaternary succession and part of the Pliocene in Site 683 is dominated by vermiculitic expanding phases and an E/I ratio of about 0.8 . There may be a slight decrease in E/I ratio with depth in the upper part of the succession, as observed at Site 688 . The transition to higher values occurs at approximately 200 to $210 \mathrm{~m}$, but is not as clearly observed as in other wells. Below $200 \mathrm{~m}$, the E/I ratio increases with depth from around 1.5 to approximately 4 . In the middle Miocene, ash layers seem abundant, and samples near such layers show higher than average smectite contents. Again, the chlorite plus kaolinite/illite ratio is relatively constant throughout the succession. The two Eocene samples from the base of Hole $683 \mathrm{~B}$ show $\mathrm{E} / \mathrm{I}$ ratios of 6 and 10 , and a lower chlorite plus kaolinite/illite ratio.

\section{Site 685}

Site 685 indicates similar variation to Site 683 . The Quaternary succession shows a gradual decrease in the E/I ratio with depth, with a sharp transition to higher values below the unconformity at the base. The accreted upper Miocene succession below shows considerable variation, presumably facies-related, but a strong overall increase in the E/I ratio occurs with depth. An ash layer contains considerably higher smectite content than average. Again, the chlorite plus kaolinite/illite ratio is constant through the succession.

\section{Site 686}

Site 686 is situated in the West Pisco Basin. It differs from the main north-south transects through the Lima and Trujillo basins in that smectite is more abundant in the Quaternary succession. The E/I ratio averages 2, and the d-spacing of the 001 peak is usually dominated by a $17 \AA$ spacing, although many samples show a $16.3 \AA$ spacing. There is no evidence of any depth-related changes. Most of the differences observed between samples are at the limits of experimental error, although there seems to be a correlation between low E/I ratio and low (001) spacing. Some hint of a $10-\mathrm{m}$ periodicity exists in the E/I values, which may be related to cyclical climatic changes. The chlorite plus kaolinite/illite ratio is virtually constant throughout the succession and is identical to that observed in the northern and southern transects.

\section{Site 687}

Site 687 is situated at the southern-most end of the Lima Basin. Although samples are few and X-ray intensities are low, the Quaternary sediments above $25 \mathrm{~m}$ show an E/I ratio below 1 , with an expandable phase that is mainly vermiculitic in composition. Below $25 \mathrm{~m}$, the remaining $75 \mathrm{~m}$ of Quaternary sediments and $75 \mathrm{~m}$ of Pliocene sediments show E/I ratios of 1.7 to 2.3 , dominated by smectite. Chlorite plus kaolinite/illite ratios are constant and similar to those observed in previous holes, with the exception of Interval $112-687 \mathrm{~B}-3 \mathrm{H}-5,30 \mathrm{~cm}$, at $22.5 \mathrm{~m}$, which shows a significantly higher kaolinite content.

Thus, the upper $25 \mathrm{~m}$. of the section shows values more characteristic of the Lima and Trujillo basins, whereas the lower part of the section is more typical of the West Pisco Basin.

\section{DISCUSSION}

\section{Quaternary}

The most significant variation in the composition of the clay minerals within these sediments is that while the chlorite:kaolinite:illite ratio of post-Oligocene silts and muds remains constant, both spatially and temporally, the ratio of these minerals with respect to "expanding phases" varies greatly. Although these expanding phases comprise both smectite and vermiculite (plus minor amounts of mixed-layer chlorite-smectite and/or chlorite-vermiculite), there is a clear correspondence between high $\mathrm{E} / \mathrm{I}$ ratio and the dominance of smectite as the expanding phase. Thus, most of the variation in clay minerals appears to result from "dilution" of a relatively constant illite-chlorite-kaolinite-(vermiculite) assemblage by smectite.

The status of vermiculite is less clear. It seems to be most abundant in Quaternary sediments, and it increases in abundance landward. Vermiculitic clay minerals are extremely common products of rock weathering and soil forming processes in a wide variety of climates and rock types. These minerals are most abundant in immature soils, where chemical weathering is of low intensity; more intense weathering leads to its replacement by smectite (Velde, 1985). Vermiculite has been reported from immature Andean mountain soils of Bolivia, along with illite, kaolinite, illite/vermiculite, and chlorite (Wilke and Zech, 1987). Many immature soils produce a range of vermiculitic expanding phases, including chlorite-vermiculite, hydrobiotite (illite-vermiculite), and intergrade material. Despite its widespread occurrence in soils, vermiculite has rarely been reported from ocean sediments and sedimentary rocks in general. This is probably because of problems with recognition in the presence of smectite. Chamley (1980) reported vermiculite and vermiculitic mixed-layer clays from lower Miocene to Pleistocene sediments of the Shikoku Basin in the Philippine Sea (Site 442) and suggested a continental pedogenic origin from eastern Asia. In contrast, Claridge and Campbell (1986) reported vermiculite from Antarctic Cenozoic sediments from McMurdo Sound, which they suggested was derived by glacial erosion.

Vermiculite has also been recorded as the product of hydrothermal processes in the Red Sea (Singer and Stoffers, 1987). Increasing concentration landward makes such an origin unlikely in this study, and most probably this vermiculite represents incorporation of continental detritus into the sediment. 
When the E/I ratio rises much above 2, the expandable phase tends to be dominated by smectite, and it is often difficult to detect whether vermiculite is still present. Where the ratio is below 1, vermiculitic phases are usually dominant. This suggests that the addition of smectite is occurring, rather than replacement of vermiculite by smectite. Where smectite is of lowest abundance, the $\mathrm{E} / \mathrm{I}$ ratio is constant at about 0.8 . Most likely, the vermiculite co-varies with illite, chlorite, and kaolinite, and a constant ratio is maintained, although one cannot verify this where smectite is abundant.

The chlorite plus kaolinite/illite ratio may have been relatively constant over the whole area since Eocene time. Studies of the clay mineral contents of Peruvian rivers (Scheidegger and Krissek, 1982) show a considerable variation in illite:chlorite:kaolinite ratios that is not reflected in the composition of the sediments. The constant chlorite plus kaolinite/ illite ratio found in the sediments suggests that considerable mixing has occurred with respect to these components, and also that the source and transport of these mineral phases has changed little since post-Eocene time. This seems to suggest that climatic variation has also been unimportant with respect to these phases.

An origin within immature mountainous soils seems most likely for the illite-chlorite-kaolinite-vermiculite assemblage. Western Peru is dominated by a narrow arid coastal plain backed by the Andes, which reach more than $6000 \mathrm{~m}$. As a consequence of the cold northerly-flowing Humboldt Current, desert or semi-desert vegetation is present over most of the west Andean slope south of $6^{\circ} \mathrm{S}$. The presence of the Humboldt Current system since at least earliest Miocene time would account for the consistency in these clay minerals. Periodic El Niño events produce localized extremely heavy rainfall and flash floods on the coastal desert strip. Such conditions would help prevent the formation of mature soils and only limited chemical weathering would be expected. Eolian transport of material from the desert plains may also be important between floods.

The origin of smectite is more problematical, because it may be both allogenic and authigenic. In Quaternary sediments from Site 686 in the West Pisco Basin, the E/I ratio is considerably higher than that from the more northerly sites in the Lima and Trujillo basins. In addition, the expandable phase tends to be more smectitic. Scheidegger and Krissek (1982) presented clay-mineral data for sediment from 41 Peruvian rivers. They showed a transition from an illitechlorite dominated province north of $14^{\circ} \mathrm{S}$ to a smectite dominated province to the south.

The composition of the suspended sediment in the rivers can be related to differences in provenance and volcanic activity. North of $14^{\circ} \mathrm{S}$, the surface geology is dominated by a plutonic igneous terrane, with granodioritic batholiths and associated metamorphic rocks and lesser volcanics. South of $14^{\circ} \mathrm{S}$, the gabbroic San Nicholas Batholith and extensive basic volcanics are dominant. Such basic rocks are likely to weather more rapidly to smectite in an arid or semi-arid environment. Products of dominantly andesitic Tertiary volcanic activity are present continuously along the Andean chain. However, several volcanic "gaps" are present within the Quaternary that coincide with regions of low Benioff zone dip. These gaps are thought to relate to the interaction of aseismic ridges with Andean subduction zone (Nur and Ben-Avraham, 1982). Quaternary volcanic activity in northern Peru is restricted to south of $9^{\circ} \mathrm{S}$, and recent activity is restricted to south of $16^{\circ} \mathrm{S}$ (Donnelly, 1976). This is caused by a change to a lower subduction angle, probably related to the migration of the Nazca Ridge along this region since late Miocene time (von Huene et al., 1988).
Clearly, this volcanic gap is reflected in the composition of the river sediments, and most likely the greater smectite abundance in the southerly West Pisco Basin is a direct consequence of source rocks in the hinterland more favorable to its production.

Site 687 is situated at the southern end of the Lima Basin and shows a change below $25 \mathrm{~m}$ from a vermiculite-dominated assemblage, similar to the main Lima and Trujillo basin sequences, to a smectite-dominated one below, similar to that observed at Site 686 in the West Pisco Basin. This may have resulted from separation of the West Pisco Basin by local uplift of the outer-shelf high during the Quaternary. Alternatively, it may reflect a change in the local current regime or in source material related to southerly migration of volcanic activity.

In the southern transect of this study, the E/I ratio increases seaward. Site 681 , the most landward site drilled, shows a lower E/I ratio than Sites 679 and 680 . Rosato and Kulm (1981) in their clay mineral study of surficial sediments of the Peru continental margin also showed a general seaward increase in smectite abundance. Although the relative contribution of individual rivers is not known, the average abundance of expandable minerals in suspended sediment from rivers north of $14^{\circ} \mathrm{S}$ is low $(<20 \%)$ (Scheidegger and Krissek, 1982). Although no distinction between vermiculite and smectite was made in the river study, and comparison of absolute abundances of clay minerals between different laboratories is notoriously difficult, it seems that an additional source of smectite is required.

Several alternative sources of smectite are likely. Eolian transport of material from the coastal deserts is probably important (Scheidegger and Krissek, 1982). Prospero and Bonatti (1969) reported smectite-rich dusts from the southeast Pacific to the north of the Peru margin. If the airborne dusts from the coastal deserts are more smectite-rich than the fluvial flux, then an increase in smectite abundance might be expected seaward as the fluvial contribution diminished. Such an enrichment might be expected because dusts would be homogenized over a larger source area, reducing the effect of the low smectite abundance between $9^{\circ}$ and $14^{\circ} \mathrm{S}$. Some support for eolian supply is provided by Quaternary sediments from Site 321 , Leg 57, situated on the Nazca Plate to the west of the Peru trench. These sediments show a broadly similar claymineral assemblage, with a slightly enhanced E/I ratio (Zemmels and Cook, 1976).

Authigenesis from volcanic ash and/or labile primary minerals is another probable alternative source of smectite. A Quaternary ash from Site 681 showed an enhanced E/I ratio and a prominent smectite peak. In addition, smectite has been found to completely dominate the $<2-\mu \mathrm{m}$ fraction of partially altered surficial ash layers situated near the Nazca Ridge (Rosato and Kulm, 1981). A final source of additional smectite might be provided by current-derived material from more smectite-rich areas to the north or south, via the northwardflowing Peru Current or the southward-flowing Poleward Undercurrent.

With the exception of Site 682 , where the sampling density was low, all the slope sites show a decrease in E/I ratio with depth within the Quaternary succession. This might be explained by a decrease in the relative contribution of fluvial supply in the later Quaternary. Alternatively, incorporation of slumped or reworked material from upslope may have been more important in the older sediments.

Although close sampling was undertaken in the Quaternary succession of Sites 680 and 686 with a view to recognizing cyclical climatic control, only limited evidence of such control was obtained. In Site 680 , a broad correlation appears to be 
Table 1. Clay-mineral data, Site 679.

\begin{tabular}{|c|c|c|c|c|c|c|c|c|}
\hline Sample $(\mathrm{cm})$ & Palygorskite & Expandable & Illite & Chlorite & Kaolinite & $\begin{array}{l}\text { Chlorite- } \\
\text { smectite }\end{array}$ & Clinoptilolite & $\begin{array}{c}\mathrm{d}(001)(\mathrm{A}) \text { of } \\
\text { expanding phase }\end{array}$ \\
\hline \multicolumn{9}{|l|}{ Hole 679D: } \\
\hline $1 \mathrm{H}-1,106-108$ & 0 & 39 & 44 & 11 & 6 & & & 16.2 \\
\hline $2 \mathrm{H}-1,120-122$ & 0 & 47 & 40 & 8 & 5 & + & & 16.2 \\
\hline $3 \mathrm{H}-1,44-46$ & 0 & 45 & 45 & 7 & 3 & + & & 15.5 \\
\hline $4 \mathrm{H}-1,100-102$ & ? & ? & ? & ? & ? & ? & ? & $?$ \\
\hline $5 \mathrm{H}-1,16-18$ & 0 & 47 & 42 & 7 & 4 & + & & 15.8 \\
\hline $6 \mathrm{H}-1,86-88$ & 0 & 65 & 26 & 5 & 4 & & & 16.2 \\
\hline $7 \mathrm{H}-1,46-48$ & 0 & 65 & 26 & 5 & 4 & & & 16.7 \\
\hline $8 \mathrm{H}-1,88-90$ & 0 & 59 & 31 & 7 & 3 & & & 15.8 \\
\hline $9 \mathrm{H}-1,111-113$ & 0 & 64 & 26 & 6 & 4 & + & & 16.4 \\
\hline $10 \mathrm{H}-1,68-70$ & 0 & 66 & 24 & 6 & 4 & + & & 16.1 \\
\hline $11 \mathrm{H}-1,44-46$ & 0 & 73 & 18 & 6 & 3 & + & & 16.8 \\
\hline $12 \mathrm{H}-1,23-25$ & ? & ? & ? & $?$ & ? & ? & ? & $?$ \\
\hline $13 \mathrm{X}-1,33-35$ & 0 & 74 & 20 & 3 & 3 & + & & 16.2 \\
\hline $14 \mathrm{X}-1,36-38$ & 0 & 74 & 20 & 4 & 2 & + & & 16.7 \\
\hline $15 X-1,34-36$ & 0 & 67 & 21 & 8 & 4 & + & & 16.8 \\
\hline $17 X-1,104-106$ & 0 & 85 & 11 & 3 & 1 & + & & 16.7 \\
\hline $18 \mathrm{X}-1,120-122$ & 0 & 75 & 16 & 6 & 3 & + & & 17.0 \\
\hline $19 X-1,65-67$ & 0 & 82 & 14 & 2 & 2 & + & & 16.8 \\
\hline $20 X-1,69-71$ & 0 & 75 & 17 & 5 & 3 & + & & 17.0 \\
\hline $21 \mathrm{X}-\mathrm{CC}, 7-9$ & 0 & 82 & 12 & 4 & 2 & + & & 17.0 \\
\hline $22 \mathrm{X}-\mathrm{CC}, 9-11$ & 0 & 79 & 15 & 4 & 2 & + & + & 17.0 \\
\hline $23 \mathrm{X}-\mathrm{CC}, 5-7$ & 0 & 74 & 18 & 5 & 3 & + & & 16.8 \\
\hline $24 \mathrm{X}-1,22-24$ & 0 & 77 & 17 & 4 & 2 & + & + & 16.8 \\
\hline $26 \mathrm{X}-1,44-46$ & 0 & 82 & 14 & 3 & 1 & + & + & 16.8 \\
\hline \multicolumn{9}{|l|}{ Hole 679E: } \\
\hline $3 X-1,50-52$ & 0 & 94 & 4 & 1 & 1 & & + & 17.0 \\
\hline $4 X-1,23-25$ & 0 & 91 & 7 & 1 & 1 & & + & 17.0 \\
\hline $5 X-1,84-86$ & 0 & 91 & 7 & 1 & i & & + & 16.8 \\
\hline $6 \times-1,67-69$ & 0 & 81 & 16 & 1 & 2 & + & & 16.8 \\
\hline $7 X-1,37-39$ & 0 & 84 & 13 & 1 & 2 & & + & 17.0 \\
\hline $8 X-1,20-22$ & 0 & 92 & 6 & 1 & 1 & & + & 17.0 \\
\hline $9 X-1,40-42$ & 0 & 89 & 8 & 1 & 2 & + & + & 17.0 \\
\hline $10 X-1,43-45$ & 0 & 84 & 12 & 2 & 2 & + & + & 17.0 \\
\hline $11 X-1,51-53$ & 0 & 84 & 11 & 3 & 2 & & & 17.0 \\
\hline $12 \mathrm{X}-1,54-56$ & 0 & 91 & 7 & 1 & 1 & + & & 17.0 \\
\hline
\end{tabular}

$+=$ present; ? = not determined-low intensity.

present between E/I ratio and organic matter, at least in the upper $20 \mathrm{~m}$. Such a relationship is difficult to explain unequivocally, but one possibility is that it represents an increase in the eolian contribution during periods of stronger southeast trade winds driving more intense upwelling, and bringing additional material from more smectite-rich areas to the south. At Site 686 there may be some suggestion of a $10-\mathrm{m}$ periodicity in the $\mathrm{E} / \mathrm{I}$ ratios in Hole $686 \mathrm{~B}$, although statistically analysis and even closer sampling will be required to verify this.

\section{Miocene-Pliocene}

With the exception of Site 684 , all sites show a relatively sharp increase in expandables with depth at some point within the Quaternary or Pliocene. A similar change is recorded at Site 321 (Leg 34), situated on the Nazca Plate (Fig. 1), directly to the west of the southern transect (Zemmels and Cook, 1976). Here, the E/I ratio increases sharply from 2 to 7 at the Quaternary/Pliocene boundary.

This is almost certainly related to the cessation of major volcanic activity within the central Peru section during the Quaternary and the creation of the volcanic gap. Noble et al. (1974) indicated that major pulses of volcanic activity occurred during the late Eocene and early and middle Miocene, followed by intense volcanism and plutonism through the Pliocene. Such material would be expected to produce smectite both as a result of weathering and of devitrification. Much early and middle Miocene smectite is highly crystalline, indicating a probable in-situ origin.
Cessation of volcanicity might be expected to occur earlier in the north as the Nazca Ridge was subducted progressively southward along the margin. This seems to be the case at Site 684 in the northern transect, with low E/I ratios in the Pliocene and upper Miocene. In the northern transect, subduction of the ridge took place in late Miocene time, about $7.5 \mathrm{Ma}$, whereas in the southern transect, subduction occurred during the Pliocene, about 4.5 Ma (Suess, von Huene, et al., 1988).

\section{Eocene-Oligocene}

Eocene sediments show a much more variable clay mineral composition, presumably as a result of the wide facies variation and alternating shallow shelf and upper-slope depths of sedimentation. In contrast to the younger sediments, there is marked variability in the chlorite:kaolinite:illite ratios. This probably reflects more variable climatic conditions prior to the dominant stabilizing influence of the Humboldt Current. Most Eocene sediments examined contain predominately smectite. Chamley (1980), in his study of sediments from the Shikoku Basin, attributed the transition from a smectite-dominated assemblage to an illite-chlorite-kaolinite-vermiculite-dominated assemblage to the effects of global post-Eocene cooling.

The origin of palygorskite is ambiguous, although its association with carbonate and only moderately crystallized smectite might suggest a detrital, rather than volcanic, origin.

The presence of opal-CT within the middle Eocene suggests that there may have been an original diatomaceous component, indicating possible upwelling off Peru prior to the terminal Eocene event (Marty et al., 1988). 


\section{ACKNOWLEDGMENTS}

A.E.S. Kemp acknowledges financial support from the Natural Environmental Research Council for attending Leg 112 and sampling at ODP in Texas. We thank N. E. Wells for informative discussions on S. E. Pacific oceanography and climatology. We thank Robin Saunders and Danny Adams for their expert technical assistance.

\section{REFERENCES}

Biscaye, P., 1965. Mineralogy and sedimentation of recent deep-sea clay in the Atlantic Ocean and adjacent seas and oceans. Geol. Soc. Am. Bull., 76: 803-832.

Chamley, H., 1980. Clay sedimentation and paleoenvironment in the Shikoku Basin since the middle Miocene (DSDP Leg 58, Northern Philippine Sea). In Klein, de V. G., Kobayashi, K., et al., Init. Repts. DSDP, 58: Washington (U.S. Govt. Printing Office), 669 678.

Claridge, G.G.C., and Campbell, I. B., 1986. Clay mineralogy. In Barrett, P. J. (Ed.), Antarctic Cenozoic History from the MSSTS1 drillhole, McMurdo Sound. DSIR Bull. New Zealand Dept Sci. Ind. Res., 237: 153-156.

Donnelly, T. W., 1976. Tertiary explosive volcanic activity in the eastern equatorial Pacific Ocean: Sites 320 and 321, DSDP Leg 34. In Yeats, R. S., Hart, S. R., et al., Init. Repts DSDP, 34: Washington (U.S. Govt. Printing Office), 605-609

Marty, R., Dunbar, R., Martin, J. B., and Baker, P., 1988. Late Eocene diatomite from the Peruvian coastal desert, coastal upwelling in the eastern Pacific and Pacific circulation before the terminal Eocene event. Geology, 16:818-822.

McEwen, D.M.C., and Wilson, M. J., 1980. Interlayer and intercalation complexes of clay minerals. In Brindley, G. W., and Brown, G. (Eds.), Crystal Structures of Clay Minerals and Their X-Ray Identification: London (Mineral. Soc.), 197-248.

Noble, D. C., McKee, E. H., Farrar, E., and Petersen, U., 1974. Episodic Cenozoic volcanism and tectonism in the Andes of Peru. Earth Planet. Sci. Lett., 21:213-220.
Nur, A., and Ben-Avraham, Z., 1983. Volcanic gaps due to oblique consumption of aseismic ridges. Tectonophysics, 99:355-362.

Prospero, J. M., and Bonatti, E., 1969. Continental dust in the atmosphere of the eastern equatorial Pacific. J. Geophys. Res., $74: 3362-3371$.

Rosato, V. J., and Kulm, L. D., 1982. Clay mineralogy of the Peru continental margin and the adjacent Nazca Plate. In Kulm, L. D., Kymond, J., Dasch, E. J., and Hussong, D. M. (Eds.), Nazca Plate: Crustal Formation and Andean Convergence. Geol. Soc. Am. Mem., 154:545-568.

Scheidegger, K. F., and Krissek L. A., 1982. Dispersal and deposition of eolian and fluvial sediments off Peru and northern Chile. Geol. Soc. Am. Bull., 93:150-162.

Singer, A., and Stoffers P., 1987. Mineralogy of a hydrothermal sequence in a core from the Atlantis II Deep, Red Sea. Clay Minerals, 22:251-267.

Suess, E., von Huene, R., et al., 1988. Proc. ODP, Init. Repts., 112: College Station, TX (Ocean Drilling Program).

Velde, B., 1985. Clay Minerals: Amsterdam (Elsevier), Developments in Sedimentology, Vol. 40.

von Huene, R., Suess, E., and Shipboard Scientific Party, 1988. Ocean Drilling Program Leg 112, Peru continental margin: Part 1, Tectonic History. Geology, 16:934-938.

Wilke, B. M., and Zech, W., 1987. Mineralogies of silt and clay fractions of twelve soil profiles in the Bolivian Andes. Geoderma, 39:193-208.

Zemmels, I., and Cook, H. E., 1976. X-ray mineralogy data from the Nazca Plate Leg 34 Deep Sea Drilling Project. In Yeats, R. S., Hart, S. R., et al., Init. Repts. DSDP, 34: Washington (U.S. Govt. Printing Office), 605-609.

Date of initial receipt: 9 January 1989

Date of acceptance: 23 August 1989

Ms 112B-137 
Table 2. Clay-mineral data, Site 680.

\begin{tabular}{|c|c|c|c|c|c|c|c|c|}
\hline Sample (cm) & Palygorskite & Expandable & Illite & Chlorite & Kaolinite & $\begin{array}{l}\text { Chlorite- } \\
\text { smectite }\end{array}$ & Clinoptilolite & $\begin{array}{l}\mathrm{d}(001)(\mathrm{A}) \text { of } \\
\text { expanding phase }\end{array}$ \\
\hline \multicolumn{9}{|l|}{ Hole 680B: } \\
\hline $1 \mathrm{H}-1,108-110$ & 0 & 34 & 50 & 11 & 5 & & & 16.1 \\
\hline $1 \mathrm{H}-2,57-59$ & 0 & 35 & 47 & 13 & 5 & & & 16.1 \\
\hline $1 \mathrm{H}-2,130-132$ & 0 & 30 & 48 & 16 & 6 & & & 15.8 \\
\hline $1 \mathrm{H}-3,57-59$ & 0 & 29 & 51 & 14 & 6 & & & 15.8 \\
\hline $1 \mathrm{H}-3,121-123$ & 0 & 31 & 48 & 15 & 6 & & & 16.1 \\
\hline $1 \mathrm{H}-4,6-8$ & 0 & 30 & 48 & 14 & 8 & + & & 16.1 \\
\hline $1 \mathrm{H}-4,78-80$ & 0 & 33 & 49 & 12 & 6 & & & 16.4 \\
\hline $1 \mathrm{H}-\mathrm{CC}, 17-19$ & 0 & 34 & 49 & 12 & 5 & & & 16.4 \\
\hline $2 \mathrm{H}-1,16-18$ & 0 & 33 & 48 & 13 & 6 & + & & 16.2 \\
\hline $2 \mathrm{H}-1,121-123$ & 0 & 37 & 48 & 10 & 5 & + & & 16.1 \\
\hline $2 \mathrm{H}-2,27-29$ & 0 & 37 & 45 & 12 & 6 & & & 15.2 \\
\hline $2 \mathrm{H}-2,128-130$ & 0 & 56 & 31 & 9 & 4 & + & & 17.0 \\
\hline $2 \mathrm{H}-3,53-55$ & 0 & 38 & 45 & 12 & 5 & + & & 15.8 \\
\hline $2 \mathrm{H}-3,127-129$ & 0 & 28 & 51 & 14 & 7 & & & 16.1 \\
\hline $2 \mathrm{H}-4,36-38$ & 0 & 30 & 50 & 12 & 8 & & & 16.4 \\
\hline $2 \mathrm{H}-4,137-139$ & 0 & 36 & 47 & 12 & 5 & + & & 15.5 \\
\hline $2 \mathrm{H}-5,40-42$ & 0 & 29 & 50 & 15 & 6 & + & & 16.1 \\
\hline $2 \mathrm{H}-5,117-119$ & 0 & 27 & 52 & 14 & 7 & + & & 16.1 \\
\hline $2 \mathrm{H}-6,31-33$ & 0 & 32 & 49 & 13 & 6 & + & & 16.1 \\
\hline $2 \mathrm{H}-6,126-128$ & 0 & 28 & 50 & 16 & 6 & + & & 16.1 \\
\hline $2 \mathrm{H}-7,27-29$ & ? & $?$ & $?$ & $?$ & $?$ & $?$ & ? & $?$ \\
\hline $3 \mathrm{H}-1,34-36$ & 0 & 27 & 51 & 17 & 5 & + & & 16.1 \\
\hline $3 \mathrm{H}-1,93-95$ & 0 & 42 & 45 & 8 & 5 & + & & 17.0 \\
\hline $3 \mathrm{H}-1,135-137$ & 0 & 35 & 46 & 13 & 6 & + & & 15.8 \\
\hline $3 \mathrm{H}-2,34-36$ & 0 & 39 & 46 & 12 & 3 & + & & 15.8 \\
\hline $3 \mathrm{H}-2,114-116$ & 0 & 31 & 52 & 11 & 6 & & & 15.8 \\
\hline $3 \mathrm{H}-3,34-36$ & 0 & 25 & 54 & 14 & 7 & & & 15.8 \\
\hline $3 \mathrm{H}-3,102-104$ & 0 & 34 & 49 & 13 & 4 & + & & 15.8 \\
\hline $3 \mathrm{H}-4,34-36$ & 0 & 33 & 48 & 13 & 6 & + & & 15.8 \\
\hline $3 \mathrm{H}-4,111-113$ & 0 & 41 & 44 & 9 & 6 & & & 15.2 \\
\hline $3 \mathrm{H}-5,34-36$ & 0 & 41 & 40 & 13 & 6 & + & & 15.8 \\
\hline $3 \mathrm{H}-5,93-95$ & 0 & 34 & 45 & 14 & 7 & + & & 15.8 \\
\hline $3 \mathrm{H}-6,41-43$ & 0 & 33 & 45 & 16 & 6 & & & 15.5 \\
\hline $3 \mathrm{H}-6,111-113$ & 0 & 34 & 49 & 11 & 6 & + & & 15.8 \\
\hline $3 \mathrm{H}-7,18-20$ & 0 & 31 & 48 & 14 & 7 & + & & 15.8 \\
\hline $3 \mathrm{H}-7,43-45$ & 0 & 31 & 48 & 14 & 7 & + & & 15.8 \\
\hline $4 \mathrm{H}-1,33-35$ & 0 & 29 & 51 & 14 & 6 & & & 16.1 \\
\hline $4 \mathrm{H}-1,107-109$ & 0 & 34 & 50 & 11 & 5 & + & & 16.1 \\
\hline $4 \mathrm{H}-2,33-35$ & 0 & 40 & 46 & 9 & 5 & & & 15.5 \\
\hline $4 \mathrm{H}-2,107-109$ & $?$ & $?$ & $?$ & $?$ & $?$ & ? & ? & $?$ \\
\hline $4 \mathrm{H}-3,32-34$ & ? & ? & ? & $?$ & ? & $?$ & ? & ? \\
\hline $4 \mathrm{H}-3,106-108$ & ? & ? & ? & $?$ & ? & ? & ? & $?$ \\
\hline $4 \mathrm{H}-4,33-35$ & ? & $?$ & $?$ & $?$ & $?$ & ? & ? & $?$ \\
\hline $4 \mathrm{H}-4,107-109$ & 0 & 33 & 48 & 15 & 4 & & & 16.1 \\
\hline $4 \mathrm{H}-5,15-17$ & 0 & 40 & 44 & I1 & 5 & + & & 15.8 \\
\hline $4 \mathrm{H}-5,39-41$ & 0 & 31 & 49 & 13 & 7 & + & & 16.1 \\
\hline $4 \mathrm{H}-5,71-73$ & 0 & 43 & 46 & 7 & 4 & + & & 15.8 \\
\hline $4 \mathrm{H}-5,134-136$ & 0 & 38 & 43 & 13 & 6 & & & 16.1 \\
\hline $4 \mathrm{H}-6,28-30$ & 0 & 42 & 35 & 14 & 9 & + & & 16.4 \\
\hline $4 \mathrm{H}-6,107-109$ & ? & $?$ & $?$ & $?$ & $?$ & ? & ? & $?$ \\
\hline $4 \mathrm{H}-7,6-8$ & 0 & 29 & 50 & 12 & 9 & + & & 16.1 \\
\hline $4 \mathrm{H}-7,56-58$ & 0 & 40 & 41 & 13 & 6 & & & 16.1 \\
\hline $5 \mathrm{H}-1,37-39$ & 0 & 41 & 42 & 9 & 8 & + & & 16.1 \\
\hline $5 \mathrm{H}-1,82-84$ & 0 & 45 & 38 & 11 & 6 & & & 16.4 \\
\hline $5 \mathrm{H}-1,117-119$ & 0 & 39 & 44 & 12 & 5 & + & & 16.1 \\
\hline $5 \mathrm{H}-2,37-39$ & 0 & 43 & 39 & 8 & 10 & + & & 15.8 \\
\hline $5 \mathrm{H}-2,117-119$ & 0 & 34 & 46 & 14 & 6 & + & & 16.4 \\
\hline $5 \mathrm{H}-3,37-39$ & 0 & 46 & 38 & 11 & 5 & + & & 15.5 \\
\hline $5 \mathrm{H}-3,117-119$ & 0 & 47 & 35 & 11 & 7 & + & & 16.1 \\
\hline $5 \mathrm{H}-4,37-39$ & 0 & 38 & 44 & 13 & 5 & + & & 16.1 \\
\hline $5 \mathrm{H}-4,118-120$ & 0 & 24 & 53 & 18 & 5 & + & & 16.4 \\
\hline $5 \mathrm{H}-5,37-39$ & 0 & 39 & 44 & 8 & 9 & + & & 16.1 \\
\hline $5 \mathrm{H}-5,117-119$ & ? & $?$ & $?$ & $?$ & $?$ & ? & ? & $?$ \\
\hline $5 \mathrm{H}-6,37-39$ & 0 & 33 & 49 & 8 & 10 & & & 16.1 \\
\hline $5 \mathrm{H}-6,117-119$ & ? & $?$ & $?$ & $?$ & $?$ & ? & ? & $?$ \\
\hline $5 \mathrm{H}-7,26-28$ & ? & ? & ? & $?$ & $?$ & ? & ? & $?$ \\
\hline $6 \mathrm{H}-2,79-81$ & ? & ? & ? & $?$ & $?$ & ? & ? & $?$ \\
\hline $6 \mathrm{H}-5,93-95$ & ? & ? & ? & ? & $?$ & ? & ? & ? \\
\hline $6 \mathrm{H}-5,107-109$ & ? & $?$ & ? & $?$ & $?$ & ? & ? & $?$ \\
\hline $7 \mathrm{H}-2,107-109$ & 0 & 44 & 42 & 8 & 6 & + & & 16.4 \\
\hline $7 \mathrm{H}-5,86-88$ & 0 & 56 & 30 & 10 & 4 & + & & 16.7 \\
\hline $7 \mathrm{H}-5,139-141$ & 0 & 55 & 30 & 9 & 6 & & & 17.0 \\
\hline $8 \mathrm{H}-2,62-64$ & 0 & 57 & 29 & 8 & 6 & & & 16.8 \\
\hline $8 \mathrm{H}-5,14-16$ & 0 & 59 & 29 & 6 & 6 & & & 16.8 \\
\hline $9 \mathrm{H}-2,45-47$ & 0 & 66 & 24 & 6 & 4 & + & & 16.7 \\
\hline $9 \mathrm{H}-2,33-35$ & 0 & 65 & 25 & 6 & 4 & & & 17.0 \\
\hline
\end{tabular}


Table 2 (continued).

\begin{tabular}{|c|c|c|c|c|c|c|c|c|}
\hline $9 \mathrm{H}-5,69-71$ & 0 & 61 & 27 & 7 & 5 & + & & 17.0 \\
\hline $10 \mathrm{H}-5,109-111$ & 0 & 55 & 31 & 8 & 6 & + & & 16.8 \\
\hline $12 X-C C, 4-6$ & 0 & 70 & 19 & 6 & 5 & & & 16.8 \\
\hline $14 \mathrm{X}-1,33-35$ & 0 & 73 & 19 & 5 & 3 & + & & 17.0 \\
\hline $21 X-1,76-78$ & 0 & 63 & 27 & 8 & 2 & + & & 17.0 \\
\hline $22 \mathrm{X}-\mathrm{CC}, 12-14$ & 0 & 78 & 16 & 5 & 1 & + & & 16.8 \\
\hline
\end{tabular}

$+=$ present; ? = not determined-low intensity.

Table 3. Clay-mineral data, Site 681.

\begin{tabular}{|c|c|c|c|c|c|c|c|c|}
\hline Sample $(\mathrm{cm})$ & Palygorskite & Expandable & Illite & Chlorite & Kaolinite & $\begin{array}{l}\text { Chlorite- } \\
\text { smectite }\end{array}$ & Clinoptilolite & $\begin{array}{l}\mathrm{d}(001)(\mathrm{A}) \text { of } \\
\text { expanding phase }\end{array}$ \\
\hline \multicolumn{9}{|l|}{ Hole 681B: } \\
\hline $1 \mathrm{H}-1,53-55$ & 0 & 35 & 45 & 15 & 5 & & & 16.1 \\
\hline $1 \mathrm{H}-3,53-55$ & 0 & 24 & 57 & 15 & 4 & + & & 15.5 \\
\hline $2 \mathrm{H}-2,53-55$ & 0 & 31 & 48 & 19 & 2 & & & 15.8 \\
\hline $2 \mathrm{H}-5,53-55$ & 0 & 31 & 49 & 16 & 4 & & & 15.8 \\
\hline $3 \mathrm{H}-2,53-55$ & 0 & 27 & 48 & 20 & 5 & & & 15.8 \\
\hline $3 \mathrm{H}-5,55-57$ & 0 & 39 & 42 & 11 & 8 & & & 15.5 \\
\hline $4 \mathrm{H}-1,55-57$ & 0 & 36 & 45 & 13 & 6 & & & 15.5 \\
\hline $4 \mathrm{H}-3,38-40$ & 0 & 40 & 38 & 14 & 8 & + & & 15.5 \\
\hline $5 \mathrm{H}-2,38-40$ & 0 & 28 & 49 & 17 & 6 & & & 15.5 \\
\hline $5 \mathrm{H}-4,88-90$ & 0 & 26 & 57 & 13 & 4 & & & 15.5 \\
\hline $6 \mathrm{H}-1,105-107$ & 0 & 28 & 45 & 20 & 7 & + & & 16.1 \\
\hline $7 \mathrm{H}-2,105-107$ & 0 & 35 & 45 & 16 & 4 & & & 16.5 \\
\hline $7 \mathrm{H}-4,105-107$ & 0 & 39 & 44 & 11 & 6 & & & 16.1 \\
\hline $8 \mathrm{H}-2,105-107$ & 0 & 29 & 51 & 14 & 6 & & & 16.5 \\
\hline $8 \mathrm{H}-5,105-107$ & 0 & 34 & 46 & 14 & 6 & & & 17.0 \\
\hline $9 \mathrm{H}-1,36-38$ & 0 & 34 & 48 & 12 & 6 & + & & 16.8 \\
\hline $9 \mathrm{H}-2,36-38$ & 0 & 35 & 49 & 12 & 4 & & & 17.0 \\
\hline $10 \mathrm{H}-1,36-38$ & 0 & 40 & 44 & 12 & 4 & & & 15.8 \\
\hline $10 \mathrm{H}-2,19-21$ & 0 & 49 & 39 & 7 & 5 & + & & 17.0 \\
\hline $10 \mathrm{H}-2,69-71$ & 0 & 47 & 40 & 9 & 4 & & & 16.1 \\
\hline $12 X-2,88-90$ & 0 & 41 & 42 & 13 & 4 & & & 16.1 \\
\hline $12 X-4,40-42$ & 0 & 38 & 45 & 13 & 4 & & & 16.4 \\
\hline $13 X-3,40-42$ & 0 & 48 & 39 & 10 & 3 & + & & 16.1 \\
\hline $14 X-1,28-30$ & 0 & 43 & 41 & 6 & 10 & & & 16.1 \\
\hline $14 X-4,28-30$ & ? & $?$ & $?$ & $?$ & $?$ & $?$ & $?$ & ? \\
\hline $15 X-1,69-71$ & 0 & 35 & 44 & 13 & 8 & + & & 16.4 \\
\hline $16 \mathrm{X}-1,10-12$ & 0 & 53 & 33 & 9 & 5 & & & 16.8 \\
\hline
\end{tabular}

$+=$ present; ? = not determined-low intensity. 
Table 4. Clay-mineral data, Site 682.

\begin{tabular}{|c|c|c|c|c|c|c|c|c|}
\hline Sample $(\mathrm{cm})$ & Palygorskite & Expandable & Illite & Chlorite & Kaolinite & $\begin{array}{l}\text { Chlorite- } \\
\text { smectite }\end{array}$ & Clinoptilolite & $\begin{array}{l}d(001)(A) \text { of } \\
\text { expanding phase }\end{array}$ \\
\hline \multicolumn{9}{|l|}{ Hole 682A: } \\
\hline $1 \mathrm{H}-1,60-62$ & 0 & 40 & 44 & 10 & 6 & & & 16.5 \\
\hline $2 \mathrm{H}-1,80-82$ & 0 & 38 & 45 & 12 & 5 & & & 15.8 \\
\hline $3 \mathrm{H}-1,125-127$ & 0 & 51 & 35 & 8 & 6 & & & 16.8 \\
\hline $4 \mathrm{H}-1,60-62$ & ? & $?$ & $?$ & $?$ & ? & ? & ? & $?$ \\
\hline $5 X-1,105-107$ & 0 & 31 & 53 & 12 & 4 & & & 14.7 \\
\hline $6 \mathrm{X}-1,53-55$ & 0 & 36 & 48 & 11 & 5 & & & 14.7 \\
\hline $7 X-2,40-42$ & 0 & 48 & 38 & 9 & 5 & & & 15.5 \\
\hline $8 X-1,33-35$ & 0 & 54 & 37 & 5 & 4 & & & 15.8 \\
\hline $9 \mathrm{X}-1,65-67$ & 0 & 54 & 34 & 6 & 6 & & & 15.2 \\
\hline $11 X-1,42-44$ & 0 & 65 & 26 & 6 & 3 & & & 15.5 \\
\hline $12 X-1,70-72$ & 0 & 69 & 24 & 3 & 4 & & & 17.0 \\
\hline $13 \mathrm{X}-1,70-72$ & 0 & 71 & 23 & 4 & 2 & & & 16.8 \\
\hline $14 \mathrm{X}-2,60-62$ & 0 & 69 & 28 & 1 & 2 & & & 15.9 \\
\hline $15 X-1,66-68$ & 0 & 66 & 27 & 3 & 4 & & & 16.4 \\
\hline $17 \mathrm{X}-1,56-58$ & 0 & 66 & 27 & 5 & 2 & & & 15.8 \\
\hline $18 \mathrm{X}-2,45-47$ & 0 & 62 & 29 & 4 & 5 & & & 15.5 \\
\hline $20 \times-2,73-75$ & 0 & 65 & 27 & 6 & 2 & & & 15.5 \\
\hline $21 X-1,80-82$ & 0 & 63 & 28 & 2 & 7 & & & 15.5 \\
\hline $22 \mathrm{X}-1,52-54$ & 0 & 62 & 28 & 5 & 5 & & & 15.8 \\
\hline $23 \mathrm{X}-1,41-43$ & 0 & 67 & 22 & 7 & 4 & & & 15.8 \\
\hline $24 \mathrm{X}-1,59-61$ & 0 & 60 & 27 & 8 & 5 & & & 15.8 \\
\hline $5 X-1,43-45$ & 0 & 64 & 26 & 2 & 8 & & & 16.1 \\
\hline $26 \mathrm{X}-1,34-36$ & ? & $?$ & $?$ & $?$ & $?$ & ? & ? & $?$ \\
\hline $27 \mathrm{X}-1,42-44$ & $?$ & $?$ & ? & ? & ? & $?$ & ? & $?$ \\
\hline $28 \mathrm{X}-1,23-25$ & ? & ? & ? & ? & ? & ? & ? & ? \\
\hline $29 \mathrm{X}-1,24-26$ & ? & $?$ & $?$ & $?$ & ? & $?$ & $?$ & $?$ \\
\hline $32 \mathrm{X}-\mathrm{CC}, 18-20$ & 0 & 71 & 19 & 4 & 6 & & & 16.8 \\
\hline $33 \mathrm{X}-\mathrm{CC}, 1-3$ & 0 & 67 & 21 & 5 & 7 & & & 16.7 \\
\hline $34 \mathrm{X}-3,60-62$ & 0 & 78 & 16 & 3 & 3 & & & 17.0 \\
\hline $35 \mathrm{X}-3,49-51$ & 0 & 90 & 8 & 0 & 2 & & & 17.0 \\
\hline $36 \mathrm{X}-1,55-57$ & 0 & 91 & 6 & 2 & 1 & & + & 17.0 \\
\hline $37 \mathrm{X}-1,84-86$ & 0 & 94 & 5 & 0 & 1 & & & 17.0 \\
\hline $38 X-3,52-54$ & 0 & 95 & 4 & 1 & 0 & & + & 17.0 \\
\hline $39 X-2,94-96$ & 0 & 95 & 5 & 0 & 0 & & & 17.0 \\
\hline $40 \times-2,109-111$ & 0 & 94 & 5 & 1 & 0 & & & 17.0 \\
\hline $41 \mathrm{X}-\mathrm{CC}, 4-6$ & 0 & 94 & 5 & 0 & 1 & & & 17.0 \\
\hline $42 \mathrm{X}-\mathrm{CC}, 7-9$ & 0 & 93 & 6 & 1 & 0 & & + & 17.0 \\
\hline $44 \mathrm{X}-\mathrm{CC}, 13-15$ & 0 & 92 & 7 & 1 & 0 & & + & 17.1 \\
\hline $45 X-1,33-35$ & 0 & 96 & 4 & 0 & 0 & & & 17.1 \\
\hline $46 \mathrm{X}-1,67-69$ & 0 & 94 & 6 & 0 & 0 & & & 17.1 \\
\hline $47 X-1,72-74$ & 0 & 94 & 6 & 0 & 0 & & + & 17.0 \\
\hline $48 \mathrm{X}-1,30-32$ & 0 & 96 & 4 & 0 & 0 & & + & 17.1 \\
\hline
\end{tabular}

$+=$ present; ? = not determined-low intensity. 
Table 5. Clay-mineral data, Site 683.

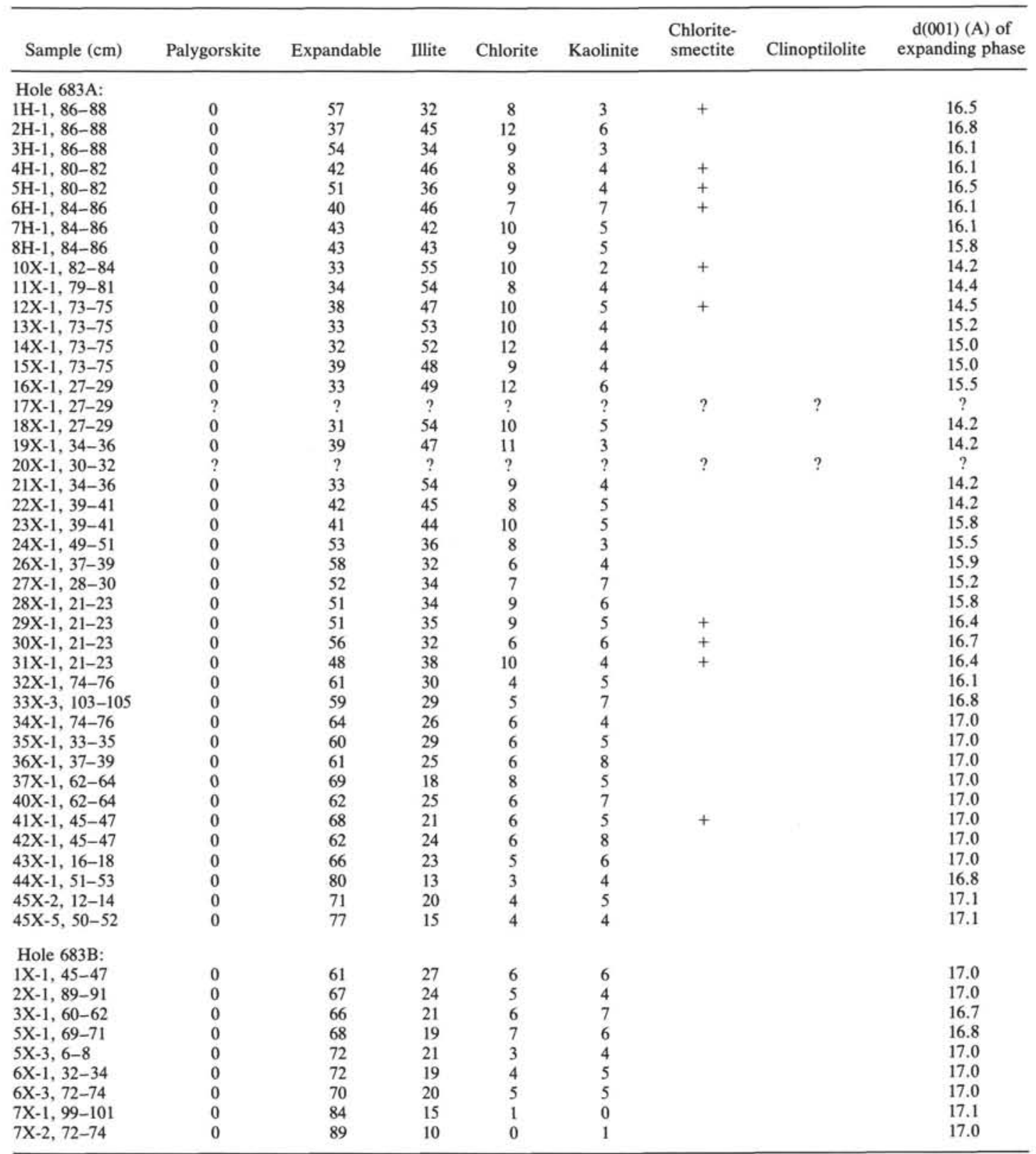

$+=$ present; $?=$ not determined-low intensity. 
Table 6. Clay-mineral data, Site 684.

\begin{tabular}{|c|c|c|c|c|c|c|c|c|}
\hline Sample (cm) & Palygorskite & Expandable & Illite & Chlorite & Kaolinite & $\begin{array}{l}\text { Chlorite- } \\
\text { smectite }\end{array}$ & Clinoptilolite & $\begin{array}{l}\mathrm{d}(001)(\mathrm{A}) \text { of } \\
\text { expanding phase }\end{array}$ \\
\hline \multicolumn{9}{|l|}{ Hole 684A: } \\
\hline $1 \mathrm{H}-2,70-72$ & 0 & 44 & 42 & 8 & 6 & & & 15.5 \\
\hline $2 \mathrm{H}-2,80-82$ & 0 & 28 & 55 & 11 & 6 & & & 16.1 \\
\hline $3 \mathrm{H}-2,90-92$ & 0 & 45 & 42 & 9 & 4 & & & 15.8 \\
\hline $4 \mathrm{H}-2,60-62$ & 0 & 43 & 43 & 8 & 6 & & & 15.5 \\
\hline $5 \mathrm{H}-2,70-72$ & 0 & 36 & 48 & 11 & 5 & & & 15.5 \\
\hline $6 \mathrm{H}-2,60-62$ & 0 & 48 & 42 & 6 & 4 & & & 15.5 \\
\hline $7 \mathrm{H}-2,70-72$ & 0 & 52 & 35 & 7 & 6 & & & 15.8 \\
\hline $8 \mathrm{H}-1,32-34$ & ? & $?$ & $?$ & $?$ & ? & $?$ & ? & $?$ \\
\hline $8 \mathrm{H}-4,50-52$ & $?$ & ? & $?$ & ? & ? & $?$ & ? & ? \\
\hline $9 X-2,50-52$ & ? & $?$ & $?$ & ? & ? & $?$ & ? & ? \\
\hline $\begin{array}{l}\text { 13X-CC, } 10-12 \\
\text { Hole } 684 \mathrm{C} \text { : }\end{array}$ & ? & $?$ & $?$ & $?$ & ? & ? & ? & ? \\
\hline $6 \mathrm{X}-1,70-72$ & 0 & 41 & 45 & 8 & 6 & & & 15.2 \\
\hline $10 \mathrm{X}-\mathrm{CC}, 10-12$ & 0 & 48 & 38 & 12 & 2 & & & 15.5 \\
\hline $11 X-1,50-52$ & ? & $?$ & $?$ & $?$ & ? & $?$ & $?$ & $?$ \\
\hline $12 \mathrm{X}-1,90-92$ & ? & $?$ & $?$ & $?$ & ? & $?$ & $?$ & $?$ \\
\hline $13 \mathrm{X}-1,110-112$ & 0 & 47 & 41 & 7 & 5 & & & 15.5 \\
\hline
\end{tabular}

$+=$ present $; ?=$ not determined-low intensity,

Table 7. Clay-mineral data, Site 685.

\begin{tabular}{|c|c|c|c|c|c|c|c|c|}
\hline Sample $(\mathrm{cm})$ & Palygorskite & Expandable & Illite & Chlorite & Kaolinite & $\begin{array}{l}\text { Chlorite- } \\
\text { smectite }\end{array}$ & Clinoptilolite & $\begin{array}{l}\mathrm{d}(001)(\mathrm{A}) \text { of } \\
\text { expanding phase }\end{array}$ \\
\hline \multicolumn{9}{|l|}{ Hole 685A: } \\
\hline $1 \mathrm{H}-1,23-25$ & 0 & 56 & 32 & 8 & 4 & + & & 16.7 \\
\hline $2 \mathrm{H}-1,23-25$ & 0 & 60 & 28 & 7 & 5 & + & & 16.8 \\
\hline $3 \mathrm{H}-1,23-25$ & 0 & 50 & 35 & 10 & 5 & + & & 16.8 \\
\hline $4 \mathrm{H}-1,88-90$ & 0 & 49 & 36 & 9 & 6 & & & 16.5 \\
\hline $5 X-1,21-23$ & 0 & 56 & 32 & 8 & 4 & + & & 16.7 \\
\hline $6 X-1,26-28$ & 0 & 50 & 37 & 9 & 4 & + & & 16.5 \\
\hline $7 X-2,26-28$ & 0 & 54 & 33 & 8 & 5 & + & & 16.4 \\
\hline $8 X-2,26-28$ & 0 & 55 & 34 & 8 & 3 & + & & 16.4 \\
\hline $9 X-2,26-28$ & 0 & 46 & 35 & 13 & 6 & & & 16.1 \\
\hline $10 X-2,26-28$ & 0 & 46 & 38 & 10 & 6 & + & & 16.2 \\
\hline $11 X-2,8-10$ & 0 & 42 & 40 & 11 & 7 & & & 16.1 \\
\hline $12 \mathrm{X}-2,8-10$ & 0 & 44 & 40 & 9 & 7 & + & & 16.1 \\
\hline $13 X-2,8-10$ & 0 & 38 & 44 & 10 & 8 & & & 15.8 \\
\hline $14 X-3,8-10$ & 0 & 41 & 44 & 10 & 5 & & & 15.8 \\
\hline $15 X-3,16-18$ & 0 & 35 & 47 & 13 & 5 & & & 15.2 \\
\hline $16 \mathrm{X}-3,16-18$ & 0 & 40 & 46 & 10 & 4 & & & 14.7 \\
\hline $17 \mathrm{X}-4,112-114$ & 0 & 33 & 47 & 14 & 6 & & & 15.8 \\
\hline $18 X-5,36-38$ & 0 & 27 & 54 & 12 & 7 & & & 15.5 \\
\hline $19 \mathrm{X}-1,19-21$ & 0 & 32 & 47 & 14 & 7 & + & & 15.8 \\
\hline $20 \mathrm{X}-1,36-38$ & 0 & 31 & 50 & 13 & 6 & & & 15.5 \\
\hline $22 \mathrm{X}-1,36-38$ & 0 & 37 & 45 & 12 & 6 & & & 15.5 \\
\hline $22 \mathrm{X}-\mathrm{CC}, 6-8$ & 0 & 33 & 48 & 12 & 7 & + & & 15.8 \\
\hline $23 \mathrm{X}-\mathrm{CC}, 6-8$ & 0 & 50 & 38 & 8 & 4 & + & & 15.5 \\
\hline $25 \mathrm{X}-\mathrm{CC}, 16-18$ & 0 & 54 & 36 & 6 & 4 & + & & 15.8 \\
\hline $27 \mathrm{X}-1,27-29$ & 0 & 57 & 32 & 6 & 5 & + & & 15.5 \\
\hline $28 \mathrm{X}-2,59-61$ & 0 & 67 & 25 & 4 & 4 & + & & 16.8 \\
\hline $29 \mathrm{X}-2,59-61$ & 0 & 68 & 23 & 5 & 4 & & & 16.5 \\
\hline $30 \mathrm{X}-2,53-55$ & 0 & 68 & 23 & 5 & 4 & & & 16.8 \\
\hline $32 \mathrm{X}-2,28-30$ & 0 & 47 & 35 & 11 & 7 & & & 16.2 \\
\hline $33 \mathrm{X}-1,12-14$ & 0 & 66 & 23 & 5 & 6 & + & & 16.8 \\
\hline $34 \mathrm{X}-2,24-26$ & 0 & 61 & 31 & 4 & 4 & + & & 16.8 \\
\hline $35 X-2,11-13$ & 0 & 68 & 23 & 5 & 4 & + & & 16.8 \\
\hline $37 \mathrm{X}-2,39-41$ & 0 & 69 & 23 & 4 & 4 & + & & 16.5 \\
\hline $38 \mathrm{X}-1,48-50$ & 0 & 61 & 27 & 5 & 7 & + & & 16.5 \\
\hline $39 \mathrm{X}-1,40-42$ & 0 & 70 & 22 & 4 & 4 & + & & 16.8 \\
\hline $41 X-1,11-13$ & 0 & 69 & 23 & 5 & 3 & + & & 16.5 \\
\hline $43 \mathrm{X}-1,38-40$ & 0 & 90 & 8 & 2 & 0 & & & 17.1 \\
\hline $43 \mathrm{X}-\mathrm{CC}, 1-3$ & 0 & 65 & 24 & 7 & 4 & + & & 16.7 \\
\hline $44 X-1,33-35$ & 0 & 91 & 6 & 1 & 2 & + & & 17.3 \\
\hline $45 \mathrm{X}-1,8-10$ & 0 & 73 & 19 & 4 & 4 & + & & 17.0 \\
\hline $47 X-1,5-7$ & 0 & 92 & 6 & 0 & 2 & & & 17.1 \\
\hline $48 \mathrm{X}-1,88-90$ & 0 & 67 & 23 & 6 & 4 & + & & 16.7 \\
\hline $49 \mathrm{X}-1,33-35$ & 0 & 67 & 24 & 5 & 4 & + & & 16.8 \\
\hline $50 X-1,45-47$ & 0 & 90 & 7 & 1 & 2 & + & & 17.0 \\
\hline $51 X-C C, 21-23$ & 0 & 92 & 6 & 2 & 0 & + & & 17.0 \\
\hline
\end{tabular}

$+=$ present; ? = not determined—low intensity. 
Table 8. Clay-mineral data, Site 686.

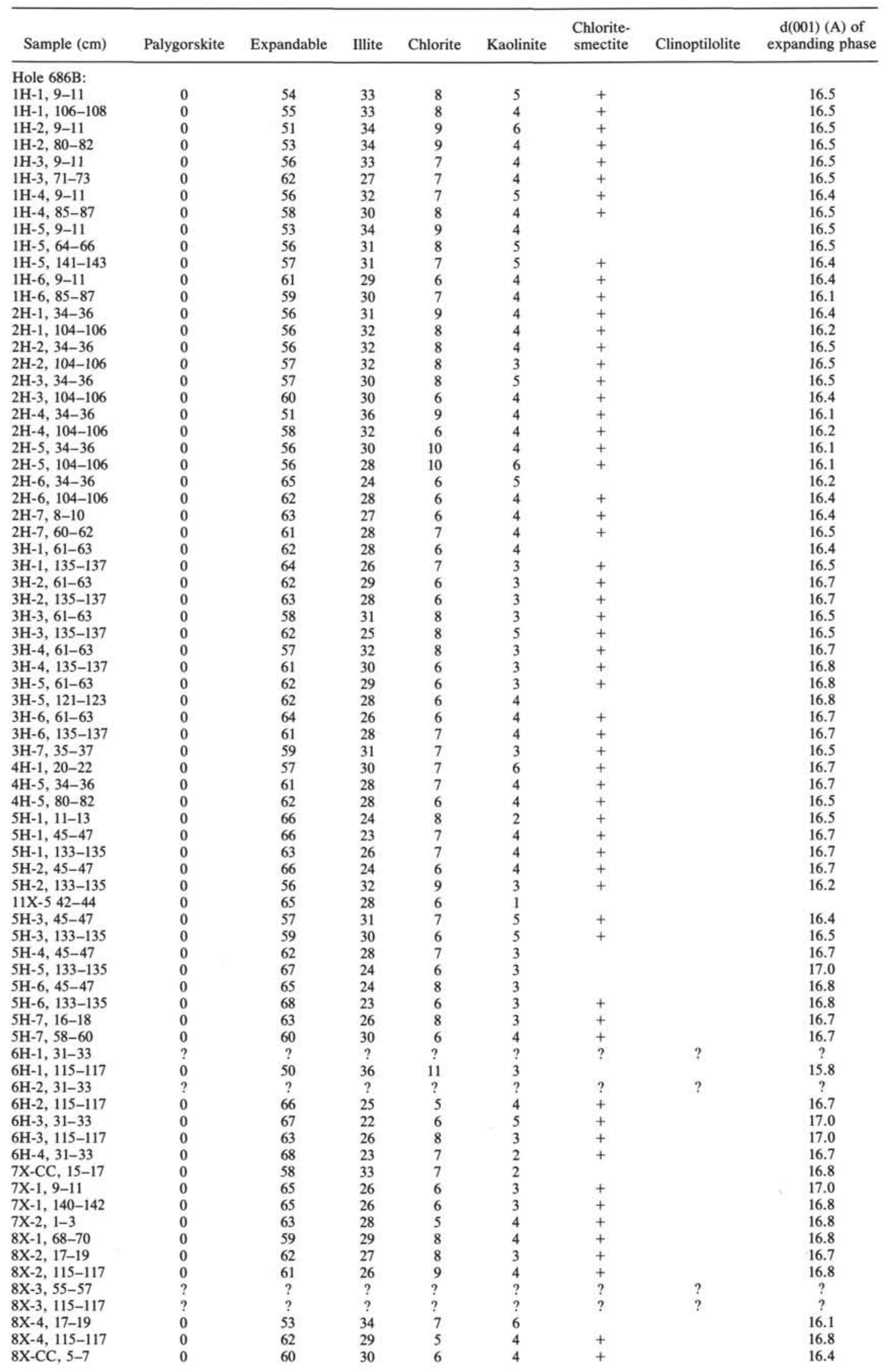


Table 8 (continued).

\begin{tabular}{|c|c|c|c|c|c|c|c|c|}
\hline Sample $(\mathrm{cm})$ & Palygorskite & Expandable & Illite & Chlorite & Kaolinite & $\begin{array}{l}\text { Chlorite- } \\
\text { smectite }\end{array}$ & Clinoptilolite & $\begin{array}{l}d(001)(A) \text { of } \\
\text { expanding phase }\end{array}$ \\
\hline $9 X-1,16-18$ & 0 & 64 & 26 & 7 & 3 & + & & 16.7 \\
\hline $9 X-2,16-18$ & 0 & 62 & 25 & 8 & 5 & + & & 17.0 \\
\hline $9 X-2,80-82$ & 0 & 70 & 21 & 7 & 2 & + & & 16.8 \\
\hline $9 X-3,16-18$ & 0 & 68 & 22 & 6 & 4 & & & 16.8 \\
\hline $9 X-3,80-82$ & 0 & 70 & 20 & 7 & 3 & + & & 17.0 \\
\hline $9 X-4,16-18$ & 0 & 56 & 32 & 8 & 4 & + & & 16.7 \\
\hline $9 X-4,80-82$ & 0 & 54 & 33 & 9 & 4 & + & & 16.4 \\
\hline $9 X-5,16-18$ & 0 & 57 & 30 & 9 & 4 & + & & 16.5 \\
\hline $9 X-5,80-82$ & 0 & 61 & 27 & 10 & 2 & + & & 16.7 \\
\hline $9 X-6,16-18$ & 0 & 64 & 26 & 10 & 0 & & & 16.8 \\
\hline $9 X-6,80-82$ & ? & $?$ & $?$ & ? & ? & ? & ? & $?$ \\
\hline $9 X-7,16-18$ & 0 & 62 & 26 & 8 & 4 & & & 16.5 \\
\hline $9 X-7,140-142$ & 0 & 63 & 28 & 8 & 1 & & & 16.7 \\
\hline $10 X-1,11-13$ & 0 & 68 & 22 & 5 & 5 & & & 17.0 \\
\hline $10 X-1,84-86$ & 0 & 62 & 26 & 8 & 4 & & & 17.1 \\
\hline $10 X-2,11-13$ & 0 & 66 & 24 & 6 & 4 & & & 16.8 \\
\hline $10 X-2,84-86$ & 0 & 60 & 28 & 8 & 4 & + & & 16.8 \\
\hline $10 \mathrm{X}-3,11-13$ & 0 & 63 & 27 & 6 & 4 & & & 16.8 \\
\hline $10 X-3,84-86$ & 0 & 64 & 26 & 7 & 3 & + & & 16.8 \\
\hline $10 X-4,11-13$ & 0 & 61 & 28 & 7 & 4 & + & & 16.8 \\
\hline $10 X-4,84-86$ & 0 & 58 & 30 & 8 & 4 & & & 16.5 \\
\hline $10 X-5,11-13$ & 0 & 59 & 31 & 7 & 3 & & & 16.5 \\
\hline $11 X-1,52-54$ & 0 & 62 & 28 & 7 & 3 & & & 16.7 \\
\hline $11 X-2,52-54$ & 0 & 67 & 26 & 5 & 2 & & & 16.8 \\
\hline $11 X-2,132-134$ & 0 & 68 & 25 & 4 & 3 & & & 16.7 \\
\hline $11 X-3,52-54$ & 0 & 60 & 29 & 8 & 3 & & & 16.7 \\
\hline $11 X-3,132-134$ & 0 & 62 & 27 & 6 & 5 & & & 17.0 \\
\hline $11 X-4,83-85$ & 0 & 70 & 23 & 5 & 2 & & & 17.0 \\
\hline $11 X-4,132-134$ & 0 & 58 & 30 & 5 & 7 & & & 16.8 \\
\hline $11 X-5,42-44$ & 0 & 65 & 28 & 6 & 1 & & & 16.7 \\
\hline $11 X-5 \quad 132-134$ & 0 & 60 & 30 & 7 & 3 & & & 16.1 \\
\hline $11 X-6,7-9$ & 0 & 66 & 24 & 6 & 4 & & & 17.0 \\
\hline $11 X-6,67-69$ & 0 & 61 & 27 & 9 & 3 & & & 17.0 \\
\hline $11 X-7,7-9$ & 0 & 55 & 34 & 6 & 5 & & & 16.1 \\
\hline $11 \mathrm{X}-\mathrm{CC}, 7-9$ & 0 & 52 & 36 & 8 & 4 & & & 16.7 \\
\hline $12 X-2,6-8$ & 0 & 58 & 34 & 6 & 2 & & & 16.4 \\
\hline $12 \mathrm{X}-4,83-85$ & 0 & 64 & 26 & 5 & 5 & & & 16.4 \\
\hline $14 X-2,6-8$ & 0 & 56 & 32 & 10 & 2 & & & 16.7 \\
\hline $15 X-2,6-8$ & ? & $?$ & $?$ & $?$ & ? & ? & ? & $?$ \\
\hline $16 \mathrm{X}-2,70-72$ & 0 & 56 & 34 & 7 & 3 & & & 16.7 \\
\hline $17 X-2,70-72$ & 0 & 66 & 24 & 5 & 5 & & & 17.0 \\
\hline $18 X-2,70-72$ & 0 & 59 & 32 & 9 & 0 & & & 16.1 \\
\hline $20 \mathrm{X}-3,70-72$ & 0 & 61 & 29 & 6 & 4 & & & 16.7 \\
\hline $21 X-3,4-6$ & 0 & 76 & 17 & 4 & 3 & & & 16.7 \\
\hline $22 \times-7,4-6$ & 0 & 73 & 19 & 5 & 3 & & & 16.7 \\
\hline $23 \mathrm{X}-2,4-6$ & 0 & 73 & 18 & 6 & 3 & & & 16.7 \\
\hline
\end{tabular}

$+=$ present; ? = not determined-low intensity.

Table 9. Clay-mineral data, Site 687.

\begin{tabular}{|c|c|c|c|c|c|c|c|c|}
\hline Sample (cm) & Palygorskite & Expandable & Illite & Chlorite & Kaolinite & $\begin{array}{l}\text { Chlorite- } \\
\text { smectite }\end{array}$ & Clinoptilolite & $\begin{array}{l}\mathrm{d}(001)(\mathrm{A}) \text { of } \\
\text { expanding phase }\end{array}$ \\
\hline \multicolumn{9}{|l|}{ Hole 687B: } \\
\hline $1 \mathrm{H}-1,30-32$ & 0 & 37 & 49 & 7 & 7 & & & 15.8 \\
\hline $1 \mathrm{H}-4,30-32$ & 0 & 46 & 41 & 8 & 5 & & & 15.5 \\
\hline $3 \mathrm{H}-2,30-32$ & 0 & 34 & 50 & 11 & 5 & & & 16.1 \\
\hline $3 \mathrm{H}-5,30-32$ & 0 & 25 & 42 & 12 & 21 & & & 16.1 \\
\hline $4 \mathrm{H}-1,93-95$ & 0 & 69 & 23 & 4 & 4 & & & 16.8 \\
\hline $5 \mathrm{H}-2,93-95$ & 0 & 53 & 31 & 12 & 4 & & & 16.8 \\
\hline $6 \mathrm{H}-2,93-95$ & ? & $?$ & $?$ & $?$ & ? & ? & ? & $?$ \\
\hline $7 \mathrm{H}-1,87-89$ & ? & ? & ? & ? & ? & ? & ? & $?$ \\
\hline $10 \mathrm{H}-1,68-70$ & 0 & 60 & 28 & 8 & 4 & & & 16.8 \\
\hline $10 \mathrm{H}-2,68-70$ & 0 & 57 & 30 & 11 & 2 & & & 16.8 \\
\hline $13 \mathrm{X}-\mathrm{CC}, 7-9$ & 0 & 52 & 32 & 12 & 4 & & & 16.8 \\
\hline $14 X-1,27-29$ & 0 & 68 & 23 & 6 & 3 & & & 16.8 \\
\hline $15 X-2,23-25$ & 0 & 62 & 27 & 8 & 3 & & & 16.8 \\
\hline $15 X-2,103-105$ & ? & $?$ & $?$ & $?$ & ? & $?$ & ? & $?$ \\
\hline $15 X-C C, 7-9$ & 0 & 58 & 32 & 7 & 3 & & & 16.1 \\
\hline $16 \mathrm{X}-1,80-82$ & ? & $?$ & $?$ & $?$ & $?$ & $?$ & ? & $?$ \\
\hline $19 \mathrm{X}-1,80-82$ & ? & ? & ? & ? & ? & ? & ? & ? \\
\hline $19 \mathrm{X}-3,80-82$ & ? & ? & $?$ & ? & ? & ? & ? & ? \\
\hline $20 \mathrm{X}-1,80-82$ & 0 & 58 & 30 & 8 & 4 & & & 16.8 \\
\hline
\end{tabular}

$+=$ present; $?=$ not determined-low intensity. 
Table 10. Clay-mineral data, Site 688.

\begin{tabular}{|c|c|c|c|c|c|c|c|c|}
\hline Sample (cm) & Palygorskite & Expandable & Illite & Chlorite & Kaolinite & $\begin{array}{l}\text { Chlorite- } \\
\text { smectite }\end{array}$ & Clinoptilolite & $\begin{array}{l}\mathrm{d}(001)(\mathrm{A}) \text { of } \\
\text { expanding phase }\end{array}$ \\
\hline \multicolumn{9}{|l|}{ Hole 688A: } \\
\hline $1 \mathrm{H}-2,32-34$ & 0 & 46 & 38 & 11 & 5 & & & 16.7 \\
\hline $2 \mathrm{H}-2,32-34$ & 0 & 62 & 28 & 6 & 4 & + & & 16.8 \\
\hline $3 \mathrm{H}-2,32-34$ & 0 & 43 & 42 & 9 & 6 & & & 16.4 \\
\hline $4 \mathrm{H}-2,32-34$ & 0 & 56 & 33 & 7 & 4 & + & & 16.5 \\
\hline $5 \mathrm{H}-2,32-34$ & 0 & 46 & 40 & 9 & 5 & & & 16.5 \\
\hline $6 \mathrm{H}-2,32-34$ & 0 & 46 & 40 & 9 & 5 & & & 16.1 \\
\hline $7 \mathrm{H}-2,32-34$ & 0 & 41 & 43 & 10 & 6 & + & & 15.8 \\
\hline $8 X-2,32-34$ & 0 & 42 & 44 & 10 & 4 & & & 16.4 \\
\hline $9 \mathrm{X}-2,32-34$ & 0 & 46 & 40 & 10 & 4 & & & 16.2 \\
\hline $10 \times-1,32-34$ & 0 & 32 & 49 & 12 & 7 & & & 16.2 \\
\hline $11 X-2,32-34$ & 0 & 36 & 47 & 11 & 6 & & & 16.4 \\
\hline $12 \mathrm{X}-1,32-34$ & 0 & 30 & 52 & 12 & 6 & & & 15.8 \\
\hline $13 X-1,32-34$ & 0 & 37 & 46 & 11 & 6 & & & 16.1 \\
\hline $14 \mathrm{X}-2,32-34$ & 0 & 36 & 47 & 12 & 5 & & & 16.1 \\
\hline $15 \mathrm{X}-2,32-34$ & 0 & 37 & 47 & 10 & 6 & & & 15.8 \\
\hline $16 \mathrm{X}-2,32-34$ & 0 & 46 & 40 & 8 & 6 & & & 15.8 \\
\hline $17 \mathrm{X}-2,36-38$ & 0 & 46 & 40 & 8 & 6 & & & 15.8 \\
\hline $18 \mathrm{X}-1,36-38$ & 0 & 45 & 41 & 9 & 5 & & & 15.8 \\
\hline $19 X-2,86-88$ & 0 & 44 & 40 & 10 & 6 & & & 15.8 \\
\hline $20 \times-1,15-17$ & 0 & 43 & 42 & 10 & 5 & & & 15.2 \\
\hline $21 X-1,54-56$ & 0 & 40 & 43 & 11 & 6 & + & & 15.8 \\
\hline $22 \mathrm{X}-1,29-31$ & 0 & 39 & 46 & 10 & 5 & & & 15.8 \\
\hline $23 \mathrm{X}-1,54-56$ & 0 & 49 & 39 & 8 & 4 & + & & 15.8 \\
\hline $24 \mathrm{X}-1,54-56$ & 0 & 40 & 44 & 10 & 6 & & & 15.5 \\
\hline $25 \mathrm{X}-1,54-56$ & 0 & 30 & 52 & 12 & 6 & & & 15.8 \\
\hline $26 \mathrm{X}-1,35-37$ & 0 & 37 & 48 & 10 & 5 & + & & 15.5 \\
\hline $27 \mathrm{X}-1,42-44$ & 0 & 54 & 33 & 8 & 5 & + & & 16.7 \\
\hline $28 \mathrm{X}-1,47-49$ & 0 & 38 & 46 & 11 & 5 & & & 15.5 \\
\hline $29 \mathrm{X}-2,47-49$ & 0 & 39 & 46 & 11 & 4 & & & 15.5 \\
\hline $30 \mathrm{X}-1,47-49$ & 0 & 41 & 43 & 10 & 6 & + & & 15.8 \\
\hline $31 \mathrm{X}-1,28-30$ & 0 & 45 & 41 & 9 & 5 & & & 15.8 \\
\hline $31 \mathrm{X}-1,28-30$ & 0 & 45 & 41 & 9 & 5 & + & & 15.8 \\
\hline $32 \mathrm{X}-1,15-17$ & 0 & 48 & 38 & 10 & 4 & & & 16.1 \\
\hline $33 X-2,15-17$ & 0 & 37 & 46 & 12 & 5 & + & & 15.5 \\
\hline $35 \times-2,15-17$ & 0 & 42 & 44 & 9 & 5 & & & 15.5 \\
\hline $36 \mathrm{X}-3,15-17$ & 0 & 50 & 37 & 9 & 4 & & & 16.1 \\
\hline $37 X-1,17-19$ & 0 & 41 & 43 & 11 & 5 & & & 15.5 \\
\hline $37 X-2,91-93$ & 0 & 35 & 49 & 13 & 3 & & & 15.2 \\
\hline \multicolumn{9}{|l|}{ Hole 688E: } \\
\hline $1 \mathrm{R}-1,48-50$ & 0 & 42 & 44 & 8 & 6 & & & 15.5 \\
\hline $2 \mathrm{R}-1,45-47$ & 0 & 37 & 49 & 9 & 5 & & & 15.5 \\
\hline $3 R-1,71-73$ & 0 & 74 & 22 & 4 & 0 & & & 15.8 \\
\hline $4 \mathrm{R}-1,36-38$ & ? & $?$ & $?$ & $?$ & $?$ & ? & $?$ & $?$ \\
\hline $5 R-2,36-38$ & 0 & 65 & 26 & 3 & 6 & & & 16.1 \\
\hline $5 R-5,36-38$ & 0 & 80 & 14 & 4 & 2 & & & 17.0 \\
\hline 6R-2, 36-38 & 0 & 82 & 14 & 2 & 2 & & & 16.8 \\
\hline $6 \mathrm{R}-5,36-38$ & 0 & 83 & 12 & 3 & 2 & & & 16.8 \\
\hline $7 \mathrm{R}-2,40-42$ & 0 & 78 & 16 & 6 & 0 & & & 16.8 \\
\hline $7 R-6,53-55$ & 0 & 85 & 12 & 2 & 1 & & & 17.0 \\
\hline $8 \mathrm{R}-2,40-42$ & 0 & 82 & 14 & 2 & 2 & & & 16.8 \\
\hline $9 \mathrm{R}-2,60-62$ & 0 & 73 & 20 & 4 & 3 & & & 17.0 \\
\hline $10 \mathrm{R}-2,60-62$ & 0 & 78 & 15 & 3 & 4 & & & 16.8 \\
\hline $12 \mathrm{R}-2,17-19$ & ? & $?$ & $?$ & $?$ & ? & $?$ & $?$ & $?$ \\
\hline 13R-CC, 17-19 & 0 & 63 & 21 & 7 & 9 & & & 16.4 \\
\hline $14 \mathrm{R}-2,17-19$ & 0 & 66 & 22 & 6 & 6 & & & 17.0 \\
\hline $15 \mathrm{R}-2,17-19$ & 0 & 63 & 22 & 9 & 6 & & & 16.8 \\
\hline $16 \mathrm{R}-1,13-15$ & 0 & 68 & 18 & 7 & 7 & & & 17.0 \\
\hline $19 \mathrm{R}-1,13-15$ & 0 & 81 & 11 & 4 & 4 & & & 17.1 \\
\hline $20 \mathrm{R}-1,13-15$ & 0 & 80 & 12 & 6 & 2 & & & 17.0 \\
\hline $22 \mathrm{R}-1,13-15$ & 0 & 81 & 13 & 3 & 3 & & & 17.0 \\
\hline $23 \mathrm{R}-2,12-14$ & 0 & 92 & 6 & 1 & 1 & & & 17.0 \\
\hline $24 \mathrm{R}-2,21-23$ & 0 & 94 & 5 & 1 & 0 & & & 17.0 \\
\hline $25 \mathrm{R}-2,21-23$ & 0 & 95 & 4 & 1 & 0 & & & 17.1 \\
\hline $26 \mathrm{R}-1,21-23$ & 0 & 97 & 3 & 0 & 0 & & & 17.3 \\
\hline $27 \mathrm{R}-1,69-71$ & 0 & 96 & 4 & 0 & 0 & & + & 17.1 \\
\hline $20 \mathrm{R}-1,103-105$ & 0 & 97 & 3 & 0 & 0 & & + & 17.1 \\
\hline $32 \mathrm{R}-1,1-3$ & 0 & 90 & 9 & 1 & 0 & & + & 17.1 \\
\hline $33 \mathrm{R}-2,28-30$ & 0 & 70 & 27 & 3 & 0 & & + & 17.1 \\
\hline 33R-CC, $6-8$ & 0 & 95 & 4 & 1 & 0 & & + & 17.3 \\
\hline $34 \mathrm{R}-2,27-29$ & 0 & 90 & 8 & 2 & 0 & & + & 17.3 \\
\hline $34 \mathrm{R}-\mathrm{CC}, 8-10$ & 0 & 95 & 4 & 1 & 0 & & + & 17.1 \\
\hline $35 \mathrm{R}-1,16-18$ & 0 & 97 & 3 & 0 & 0 & & & 17.1 \\
\hline $36 \mathrm{R}-1,67-69$ & 0 & 74 & 24 & 2 & 0 & + & & 17.1 \\
\hline $36 \mathrm{R}-2,25-27$ & 0 & 91 & 7 & 1 & 1 & + & & 17.0 \\
\hline $36 \mathrm{R}-3,24-26$ & 0 & 66 & 27 & 6 & 1 & + & & 17.0 \\
\hline
\end{tabular}


T. CLAYTON, A.E.S. KEMP

Table 10 (continued).

\begin{tabular}{|c|c|c|c|c|c|c|c|c|}
\hline Sample $(\mathrm{cm})$ & Palygorskite & Expandable & Illite & Chlorite & Kaolinite & $\begin{array}{l}\text { Chlorite- } \\
\text { smectite }\end{array}$ & Clinoptilolite & $\begin{array}{l}\mathrm{d}(001)(\mathrm{A}) \text { of } \\
\text { expanding phase }\end{array}$ \\
\hline $37 \mathrm{R}-1,23-25$ & 0 & 69 & 25 & 6 & 0 & + & & 17.0 \\
\hline $38 \mathrm{R}-3,114-116$ & 0 & 61 & 31 & 7 & 1 & + & & 17.0 \\
\hline $39 \mathrm{R}-1,106-108$ & 20 & 64 & 4 & 8 & 4 & & & 16.8 \\
\hline $41 \mathrm{R}-1,117-119$ & 0 & 91 & 2 & 5 & 2 & & & 16.8 \\
\hline $42 \mathrm{R}-1,15-17$ & 23 & 55 & 3 & 8 & 11 & & & 17.3 \\
\hline $43 \mathrm{R}-2,56-58$ & 0 & 69 & 27 & 4 & 0 & + & & 17.0 \\
\hline $44 \mathrm{R}-2,6-8$ & 0 & 77 & 21 & 2 & 0 & + & & 17.0 \\
\hline $45 \mathrm{R}-1,59-61$ & 0 & 69 & 26 & 5 & 0 & + & & 17.0 \\
\hline $45 \mathrm{R}-3,17-19$ & 0 & 70 & 25 & 5 & 0 & + & & 17.0 \\
\hline
\end{tabular}

$+=$ present $;$ ? = not determined-low intensity. 